\title{
Oral Immunization of Larvae and Juvenile of Lumpfish (Cyclopterus lumpus) against Vibrio anguillarum Does Not Influence Systemic Immunity
}

\author{
My Dang ${ }^{1}$, Trung Cao ${ }^{1}$, Ignacio Vasquez ${ }^{1}$, Ahmed Hossain ${ }^{1}$, Hajarooba Gnanagobal ${ }^{1}$, Surendra Kumar ${ }^{2}$, \\ Jennifer R. Hall ${ }^{3}$, Jennifer Monk ${ }^{4}$, Danny Boyce ${ }^{4}$, Jillian Westcott ${ }^{5}$ and Javier Santander $1, * \mathbb{D}$ \\ 1 Marine Microbial Pathogenesis and Vaccinology Laboratory, Department of Ocean Sciences, \\ Memorial University of Newfoundland, St. John's, NL A1C 5S7, Canada; tmtdang@mun.ca (M.D.); \\ ttcao@mun.ca (T.C.); ivasquezsoli@mun.ca (I.V.); ahossain@mun.ca (A.H.); hgnanagobal@mun.ca (H.G.) \\ 2 Department of Ocean Sciences, Ocean Frontier Institute, Memorial University of Newfoundland, \\ St. John's, NL A1C 5S7, Canada; surendrak@mun.ca \\ 3 Aquatic Research Cluster, CREAIT Network, Department of Ocean Sciences, Memorial University of \\ Newfoundland, St. John's, NL A1C 5S7, Canada; jrhall@mun.ca \\ 4 Dr. Joe Brown Aquatic Research Building (JBARB), Memorial University of Newfoundland, \\ St. John's, NL A1C 5S7, Canada; jmonk@mun.ca (J.M.); dboyce@mun.ca (D.B.) \\ 5 Fisheries and Marine Institute, Memorial University of Newfoundland, St. John's, NL A1C 5S7, Canada; \\ jillian.westcott@mi.mun.ca \\ * Correspondence: jsantander@mun.ca; Tel.: +1-709-8643268
}

Citation: Dang, M.; Cao, T.; Vasquez, I.; Hossain, A.; Gnanagobal, H.; Kumar, S.; Hall, J.R.; Monk, J.; Boyce, D.; Westcott, J.; et al. Oral Immunization of Larvae and Juvenile of Lumpfish (Cyclopterus lumpus) against Vibrio anguillarum Does Not Influence Systemic Immunity. Vaccines 2021, 9, 819. https:/ / doi.org/10.3390/vaccines9080819

Academic Editors: Beatriz Novoa, Patricia Pereiro and Tae-Sung Jeong

Received: 27 May 2021

Accepted: 16 July 2021

Published: 23 July 2021

Publisher's Note: MDPI stays neutral with regard to jurisdictional claims in published maps and institutional affiliations.

Copyright: (c) 2021 by the authors. Licensee MDPI, Basel, Switzerland. This article is an open access article distributed under the terms and conditions of the Creative Commons Attribution (CC BY) license (https:// creativecommons.org/licenses/by/ $4.0 /)$.
Abstract: Vibrio anguillarum, a marine bacterial pathogen that causes vibriosis, is a recurrent pathogen of lumpfish (Cyclopterus lumpus). Lumpfish is utilized as a cleaner fish in the Atlantic salmon (Salmo salar) aquaculture in the North Atlantic region because of its ability to visualize and prey on the ectoparasite sea lice (Lepeophtheirus salmonis) on the skin of Atlantic salmon, and its performance in cold environments. Lumpfish immunity is critical for optimal performance and sea lice removal. Oral vaccine delivery at a young age is the desired method for fish immunization because is easy to use, reduces fish stress during immunization, and can be applied on a large scale while the fish are at a young age. However, the efficacy of orally delivered inactivated vaccines is controversial. In this study, we evaluated the effectiveness of a V. anguillarum bacterin orally delivered to cultured lumpfish and contrasted it to an intraperitoneal (i.p.) boost delivery. We bio-encapsulated V. anguillarum bacterin in Artemia salina live-feed and orally immunized lumpfish larvae. Vaccine intake and immune response were evaluated by microscopy and quantitative polymerase chain reaction (qPCR) analysis, respectively. qPCR analyses showed that the oral immunization of lumpfish larvae resulted in a subtle stimulation of canonical immune transcripts such as il8b, il10, igha, ighmc, ighb, ccl19, ccl20, $c d 8 a, c d 74$, ifng, and $\lg p 2$. Nine months after oral immunization, one group was orally boosted, and a second group was both orally and i.p. boosted. Two months after boost immunization, lumpfish were challenged with $V$. anguillarum $\left(7.8 \times 10^{5} \mathrm{CFU}\right.$ dose $\left.^{-1}\right)$. Orally boosted fish showed a relative percentage of survival (RPS) of $2 \%$. In contrast, the oral and i.p. boosted group showed a RPS of $75.5 \%$ $(p<0.0001)$. V. anguillarum bacterin that had been orally delivered was not effective in lumpfish, which is in contrast to the i.p. delivered bacterin that protected the lumpfish against vibriosis. This suggests that orally administered V. anguillarum bacterin did not reach the deep lymphoid tissues, either in the larvae or juvenile fish, therefore oral immunization was not effective. Oral vaccines that are capable of crossing the epithelium and reach deep lymphoid tissues are required to confer an effective protection to lumpfish against $V$. anguillarum

Keywords: lumpfish; cleaner fish; fish larvae; oral vaccine; Vibrio anguillarum bacterin; vibriosis; bio-encapsulation; Artemia salina 


\section{Introduction}

Ectoparasitic sea lice infestations are a serious health issue for wild and cultured Atlantic salmon (Salmo salar) [1]. The sea louse (e.g., Lepeophtheirus salmonis) feeds on salmonid mucus and tissues leading to physiological and immune failures and may lead to death if left untreated [1,2]. Over the last few decades, the Atlantic salmon industry has used chemical and physical methods to control sea lice infestations [3,4]. The use of chemotherapeutants generates the emergence of resistance in sea lice [3] and enhances negative public opinion on the impacts of aquaculture activity on the environment. Routine mechanical treatments (e.g., abrasion and thermal treatment) used in the salmon industry to physically remove the lice have adverse effects on salmon health and welfare [4]. Currently, multiple non-medicinal methods are used in different combinations (e.g., curtains and skirts, anti-lice diets, laser, water jets, and ultrasound) as part of an integrated pest management (IPM) strategy [5]. Another current strategy to control sea lice in the North Atlantic farms is the use of cleaner fish species as a biological control $[4,6]$. The use of cleaner fish is considered an eco-friendly alternative, as it can reduce the use of chemotherapeutants, and it is less stressful to farmed fish [7]. In Atlantic Canada, both lumpfish (Cyclopterus lumpus) and cunner (Tautogolabrus adspersus) are used as cleaner fish $[8,9]$. However, lumpfish is the preferred species for the biocontrol of sea lice due to its performance in cold environments and biomass availability [10,11]. In contrast to other cleaner fish species, lumpfish actively remove sea lice from farmed salmon in cold environments, and they have been industrialized in the North Atlantic region [12-15]. Use and demand for lumpfish in salmon farms in Ireland, the United Kingdom (UK), Norway, the Faroe Islands, Iceland, and Canada have increased in recent years [13,16]. For example, 11.8 and 0.8 million juveniles were used in Norway and in the UK in 2015, respectively [17]. In 2018, approximately 30 million juvenile lumpfish were used in Norway [18]; in the UK, approximately 6 million lumpfish were used; in Iceland, approximately 3.5 million were used [19]; and approximately 300 thousand lumpfish were used in Ireland [20]. In Canada, the use of lumpfish is a very recent practice, and approximately 1 million lumpfish were used in Atlantic Canada in 2019 [19].

Similar to other finfish species, lumpfish is susceptible to different types of bacterial pathogens such as Aeromonas salmonicida, Pasteurella spp., Tenacibaculum spp., Pseudomonas anguilliseptica, and Moritella viscosa [21,22]. Vibriosis, typically caused by Vibrio anguillarum, is a prevalent pathogen in lumpfish in Newfoundland [23], but others such as V. ordalii, $V$. salmonicida, and V. splendidus also infect lumpfish elsewhere [12,24]. V. anguillarum is a Gram-negative, motile, rod-shaped bacterium and a ubiquitous marine pathogen of invertebrates and vertebrates $[25,26]$. Formalin-killed $V$. anguillarum (bacterins) serotypes $\mathrm{O} 1$ and $\mathrm{O} 2$ mixed with adjuvants are often used to formulate vaccines for different fish species, including Atlantic salmon, Atlantic cod (Gadus morhua) [27], gilthead seabream (Sparus aurata), and lumpfish [28]. Intraperitoneal (i.p.) injection is the most common method of vaccine delivery [29], but it cannot be applied to small fish. An oral-immersion vaccine is ideal for fish immunization, as it is needle-free and causes minimum stress during application [30]. However, oral vaccine delivery to small fish or larvae has been evaluated with controversial results [31]. Vaccine bio-encapsulation strategies, such as the used of Artemia salina fed with bacterin, can increase the delivery of the vaccine to small lumpfish larvae by increasing intake and can directly deliver the antigen to the fish gut [32-34].

Here, we evaluated the efficacy of a $V$. anguillarum bacterin bio-encapsulated in $A$. salina delivered as live-feed to lumpfish larvae. We determined that the oral $V$. anguillarum vaccine delivered in $A$. salina live-feed reached the lumpfish gut. Real-time quantitative polymerase chain reaction (qPCR) analyses of immune-relevant genes revealed that oral immunization modestly immune stimulated the lumpfish larvae. Nine months later, a lumpfish group was orally boosted, and an independent second group was orally and i.p. boosted. Two months later, the immunized fish groups were i.p. challenged with ten times the lethal dose $50\left(\mathrm{LD}_{50}\right)$ of V. anguillarum $\left(7.8 \times 10^{5}\right.$ colony forming units $(\mathrm{CFU})$ dose $\left.^{-1}\right)$. 
Oral immunization of lumpfish delayed mortality but did not confer protective immunity against the $V$. anguillarum challenge, which contrasts with the i.p. vaccination, which protected the fish against the lethal infection.

\section{Materials and Methods}

\subsection{Vibrio anguillarum J360 Culture Conditions}

V. anguillarum J360 serotype O2 (NCBI IDs: Chromosome 1 CP034672; Chromosome 2 CP034673; and plasmid CP034674), a local lumpfish isolate, was used in this study [23]. V. anguillarum J360 was grown in $3 \mathrm{~mL}$ of tryptic soy broth (TSB, Difco) for $24 \mathrm{~h}$ at $28^{\circ} \mathrm{C}$ with aeration (180 rpm, in an orbital shaker). Bacterial growth was monitored using spectrophotometry (Genesys 10 UV spectrophotometer, Thermo Fisher Scientific Inc., Waltham, MA, USA) and by plating to determine the CFU mL ${ }^{-1}$. When the optical density (OD600 nm) reached $\sim 0.7\left(1 \times 10^{8} \mathrm{CFU} \mathrm{mL}{ }^{-1}\right)$, the cells were harvested by centrifugation at $4200 \times g$ for $10 \mathrm{~min}$ at room temperature. The cell suspension was washed twice with phosphatebuffered saline (PBS; $136 \mathrm{mM} \mathrm{NaCl}, 2.7 \mathrm{mM} \mathrm{KCl}, 10.1 \mathrm{mM} \mathrm{Na}_{2} \mathrm{HPO}_{4}, 1.5 \mathrm{mM} \mathrm{KH} \mathrm{KO}_{4}$; $\mathrm{pH}$ 7.2) [35] at $4200 \times g$ and resuspended in $300 \mu \mathrm{L}$ of PBS $1 \mathrm{X}\left(\sim 1 \times 10^{10} \mathrm{CFU} \mathrm{mL}^{-1}\right)$. The final inoculum was serially diluted (1:10), and the concentration was determined by plate counting [36] in TSB supplemented with $1.5 \%$ bacto agar (TSA).

\subsection{Bacterin Preparation}

The bacterin preparation was conducted according to established protocols and quantified using flow cytometry enumeration [37] with modifications. First, V. anguillarum J360 was grown in $500 \mathrm{~mL}$ of TSB supplemented with a final concentration of $150 \mu \mathrm{M}$ 2,2-dipyridyl (Sigma-Aldrich, St. Louis, MO, USA) at $28{ }^{\circ} \mathrm{C}$ with aeration (180 rpm, in an orbital shaker) to induce synthesis of the iron-regulated outer membrane proteins (IROMPs) [38]. Bacterial growth was monitored spectrophotometrically until it reached $\sim 1 \times 10^{8} \mathrm{CFU}^{-1}$. V. anguillarum cells were harvested using centrifugation $(4200 \times g$ at $4{ }^{\circ} \mathrm{C}$ for $10 \mathrm{~min}$ ) and washed twice with PBS. V. anguillarum cells were fixed with buffered formalin $6 \%$ (Sigma) at room temperature for $3 \mathrm{~d}$ with gentle agitation in a rocker shaker. Cell viability was determined each day by plating onto TSA. Formalin was removed using centrifugation, and cells were then dialyzed (Spectrum ${ }^{\mathrm{TM}}$ Spectra/Por ${ }^{\mathrm{TM}}$ dialysis membrane 12-14,000 Dalton molecular weight cut-off, Thermo) in $2 \mathrm{~L}$ of PBS at $6{ }^{\circ} \mathrm{C}$ for $3 \mathrm{~d}$ with agitation. $V$. anguillarum bacterins were quantified using the BD FACS Aria II flow cytometer (BD Biosciences, San Jose, CA, USA) and BD FACS Diva v7.0 software as described previously [39]. Bacterin cells $\left(1 \times 10^{10} \mathrm{CFU} \mathrm{mL}{ }^{-1}\right)$ were stored at $4{ }^{\circ} \mathrm{C}$ until use.

\subsection{V. anguillarum Bacterin Fluorescent Labeling}

V. anguillarum bacterin was labeled with 5-([4,6-dichlorotriazinyl] amino) fluorescein hydrochloride (DTAF; Sigma) according to previously described protocols [40] with minor modifications. First, V. anguillarum bacterin $\left(\sim 1 \times 10^{10} \mathrm{CFU} \mathrm{mL}{ }^{-1}\right)$ was centrifuged at $4200 \times \mathrm{g}$ for $10 \mathrm{~min}$ and then resuspended in $950 \mu \mathrm{L}$ of bicarbonate buffer $(0.1 \mathrm{M}, \mathrm{pH} 9)$. Following that, the cells were mixed with $50 \mu \mathrm{L}$ of DTAF solution (100 $\mu \mathrm{g}$ in dimethyl sulfoxide (DMSO); Sigma) and incubated overnight at $4{ }^{\circ} \mathrm{C}$ in dark conditions. After incubation, the bacterin cells were centrifuged $(4200 \times g$ for $10 \mathrm{~min})$ and washed three times with bicarbonate buffer and were finally resuspended in PBS and kept at $4{ }^{\circ} \mathrm{C}$ until use.

Next, we describe the optimization of $V$. anguillarum bacterin bio-encapsulation in $A$. salina. To optimize bacterin bio-encapsulation in A. salina, we used the method described by Campbell et al. [32] with modifications. Additionally, we developed a semi-quantitative method to estimate the levels of bacterin bio-encapsulation in A. salina. First, A. salina nauplii were hatched from cysts according to the supplier's instructions (INVE, Salt Lake City, UT, USA) (Figure S1). After the A. salina nauplii hatched $\left(20 \mathrm{~h}\right.$ at $\left.20^{\circ} \mathrm{C}\right)$, nauplii were washed with seawater for $30 \mathrm{~min}$ (Figure S1). A. salina cultures were nutritionally supplemented with Ori-One (Skretting, Fontaine les Vervins, France) and Ori-Green (Skretting, Fontaine les Vervins, France) commercial dry microalgae extract at a ratio of 
1:1 (Ori-One:Ori-green) for $3 \mathrm{~h}$ at $20^{\circ} \mathrm{C}$. To determine the optimal time for bacterin bioencapsulation in A. salnina, supplemented A. salina nauplii were inoculated into 6 well plates with a $3 \mathrm{~mL}$ total volume per well at a density of 1000 nauplii $\mathrm{mL}^{-1}$. Additionally, a separate plate was inoculated with non-supplemented $A$. salina nauplii to determine the possible effect of nutrient supplementation on bio-encapsulation. Both groups were inoculated with DTAF-labeled $V$. anguillarum bacterin $\left(5 \times 10^{7}\right.$ cells $\left.\mathrm{mL}^{-1}\right)$. The control group was mock inoculated with seawater and used to evaluate autofluorescence. The nauplii were incubated at $20^{\circ} \mathrm{C}$ for $48 \mathrm{~h}$ to determine the optimal time for bacterin bioencapsulation (Figure S1A). A. salina samples (1 mL) were collected at 1, 3, 5, 24, 36, and $48 \mathrm{~h}$, and fixed in $10 \%$ buffered formalin. The presence of $V$. anguillarum inactivated bacterin was examined and counted using confocal microscopy (Nikon Eclipse Ti, Melville, NY, USA) to determine the number of $A$. salina containing $0 \%, 25 \%, 50 \%, 75 \%, 100 \%$ bacterin (Figure S1A). After determining the optimal time for bacterin bio-encapsulation in A. salina nauplii, we evaluated the bio-encapsulation stability at $6{ }^{\circ} \mathrm{C}$ for $6 \mathrm{~d}$ (Figure S1B). A. salina nauplii were supplemented with Ori-One, Ori-Green, and DTAF-labeled V. anguillarum bacterin at $20^{\circ} \mathrm{C}$ for $3 \mathrm{~h}$ and then placed at $6^{\circ} \mathrm{C}$ for $6 \mathrm{~d}$. The A. salina control group was mock inoculated with seawater. A. salina samples were collected each day and fixed with buffered $10 \%$ formalin. The levels of bio-encapsulation in $A$. salina were determined using confocal microscopy (Figure S1B). DTAF-labeled V. anguillarum inactivated bacterin bio-encapsulated in A. salina nauplii were used to feed the lumpfish larvae (Figure S2) and to determine the presence of $V$. anguillarum bacterin in the larvae gut compared to the non-orally immunized fish (Figure S3). Fifty lumpfish larvae were orally immunized and maintained at $6^{\circ} \mathrm{C}$ for $24 \mathrm{~h}$. The larvae gut was observed at $0,0.5,1,2,4,6$, and $24 \mathrm{~h}$ post-oral immunization using epi-fluorescence microscopy (Optika, Italy) (Figure S3).

\subsection{V. anguillarum Bacterin Bio-Encapsulation in A. salina}

Based on the vaccine bio-encapsulation optimization results, larger volumes of $A$. salina were prepared for lumpfish larvae immunization. A. salina nauplii were hatched and washed with seawater for $30 \mathrm{~min}$ and placed in $20 \mathrm{~L}$ buckets containing $15 \mathrm{~L}$ of seawater. A. salina nauplii were maintained at a density of $\sim 2.5$ million $A$. salina per liter. A. salina cultures were enriched with nutritional supplements derived from microalgae, OriOne (Skretting, France) and Ori-Green (Skretting, France) according to the manufacturer's instructions. A. salina cultures were inoculated with V. anguillarum bacterin $\left(10^{7}\right.$ cells $\left.\mathrm{mL}^{-1}\right)$ and incubated at $20^{\circ} \mathrm{C}$ for $3 \mathrm{~h}$ with aeration. Controls were mock inoculated with PBS. After $3 \mathrm{~h}$ of enrichment and bacterin bio-encapsulation, the A. salina cultures were maintained at $6{ }^{\circ} \mathrm{C}$ for $6 \mathrm{~d}$ under constant light. These cultures were used for the daily oral immunization of the lumpfish larvae (Figure S4).

\subsection{Aquafeed Coating with V. anguillarum Bacterin}

Commercial dry feed was coated with dry $V$. anguillarum bacterin to orally boost immunized fish. Ficoll, a non-toxic polymer, was used as a cryoprotectant for bacterial lyophilization [41]. Ficoll also serves as an antigen and adjuvant carrier [41-46]. To freezedry the bacterin, a formalin-killed V. anguillarum $\left(2 \times 10^{9} \mathrm{CFU} \mathrm{mL}^{-1}\right)$ suspension was mixed with Ficoll solution (20\% Ficoll400 (GE Healthcare, Sweden), $300 \mathrm{mM} \mathrm{NaCl}$ ) at a 1:1 ratio to prevent cell lysis during lyophilization. The cells were lyophilized (Edwards super module E2-M5, Edwards, UK) for 3 days. The bacterin powder was mixed with 3-4 mm commercial dry pellet (Skretting-Europa 15: crude protein (55\%), crude fat (15\%), crude fiber $(1.5 \%)$, calcium ( $3 \%)$, phosphorus $(2 \%)$, sodium ( $1 \%)$, vitamin A (5000 IU kg $\left.{ }^{-1}\right)$, vitamin D (3000 IU kg-1), and vitamin E (200 IU kg-1)) at the ratio of $0.9 \mathrm{~g}$ bacterin per $100 \mathrm{~g}$ aquafeed. After mixing the feed with the bacterin powder, a layer of cod liver oil was added ( $3 \mathrm{~mL} 100 \mathrm{~g}$ feed $^{-1}$ ), and the feed was then dried at room temperature to complete the coating process. The coated feed was stored at $4{ }^{\circ} \mathrm{C}$ until used. 


\subsection{Fish Culture Conditions}

All animal protocols required for this research were approved by the Institutional Animal Care Committee and the Biosafety Committee at Memorial University of Newfoundland (MUN). Experiments were conducted under protocols \#18-01-JS, \#18-03-JS, and biohazard license L-01. Lumpfish egg masses were in vitro fertilized and maintained in $5 \mathrm{~L}$ buckets containing UV treated ( $300 \mathrm{~mW} \mathrm{~cm}^{-2}$ ), filtered, flow-through seawater (33 ppt) at $10-10.5^{\circ} \mathrm{C}$, with $95-110 \%$ air saturation, and held under ambient photoperiod (springsummer) at the Joe Brown Aquatic Research Building (JBARB), Department of Ocean Sciences, Memorial University of Newfoundland, Canada. After embryo development was complete, the larvae were hatched and maintained in the same seawater conditions and air saturation at $10{ }^{\circ} \mathrm{C}$ until full egg yolk sac absorption and the establishment of independent feeding was achieved (Figure S2).

\subsection{Lumpfish Immunization Assays}

Lumpfish larvae were stocked in 4 tanks at a density of 2000 larvae per tank $(20 \mathrm{~L})$ with UV treated $\left(300 \mathrm{~mW} \mathrm{~cm}{ }^{-2}\right)$, filtered, flow-through seawater at $8-10{ }^{\circ} \mathrm{C}$, and with $95-110 \%$ air saturation (Figure 1). Two tanks containing lumpfish larvae (1-week post-hatch (wph)) were orally immunized with the bio-encapsulated $V$. anguillarum vaccine daily for 4 weeks. Two tanks fed containing only A. salina served as controls (Figure 1). Lumpfish larvae were fed with $A$. salina nauplii or bio-encapsulated vaccine 3 times per day $(350 \mathrm{~mL}$ of $A$. salina culture per 2000 larvae) (Figure S4). Thereafter, the fish were fed A. salina for additional $10 \mathrm{~d}$ and then fed with dry pelleted diet daily (0.75-2\% body weight). Whole larvae pool samples were collected at 0, 2, and 4 weeks post-immunization (wpi) (Figure 1). At each time point, triplicate pools of 5-10 larvae were sampled from each tank and placed in a $1.5 \mathrm{~mL}$ RNase-free tube containing $300 \mu \mathrm{L}$ of TRIzol Reagent (Invitrogen, Waltham, MA, USA), flash-frozen in liquid nitrogen, and stored at $-80{ }^{\circ} \mathrm{C}$ until processing. After 8 weeks, the juvenile lumpfish were transferred into eight $500 \mathrm{~L}$ tanks (Figure 1). The lumpfish were fed an assorted size pelleted diet for the remainder of the experiment (15 months). Nine months post-hatch, two tanks with 100 fish each $(\sim 72.1 \pm 30 \mathrm{~g})$ were orally boost immunized using commercial pellets coated with the $V$. anguillarum bacterin. Lumpfish were starved for $24 \mathrm{~h}$ pre-oral vaccination. Lumpfish were fed with $V$. anguillarum bacterin coated dry pellets three times (every 2 weeks for 3 days) at $0.75 \%$ body weight (Figure 1 ). Two control tanks were mock-orally boosted with ficoll (vaccine vehicle) coated pellets (Figure 1). Two independent groups orally boosted were additionally i.p. boosted at $40 \mathrm{wph}$ $(\sim 145 \pm 31.8 \mathrm{~g})$ with $V$. anguillarum bacterin $\left(6.3 \times 10^{8}\right.$ cells dose $\left.^{-1}\right)$. Control groups were mock-orally and i.p. boosted with the respective vaccine vehicle (Figure 1). Two months later, the animals ( 132-244 g) were transferred to the AQ3 aquatic biocontainment facility at the Cold-Ocean Deep-Sea Research Facility (CDRF) for challenge assays.

\subsection{V. anguillarum J360 Challenge Assays in Lumpfish}

The challenge assays were conducted at the CDRF AQ3 biocontainment facility under the Institutional Animal Care Committee approved protocol (18-02-JS) and established protocols [28]. First, after transfer to the AQ3 biocontainment facility, lumpfish were acclimated for 1 week under optimal conditions prior to the commencement of the challenge. Lumpfish were challenged by an i.p. injection with 7 times the lethal dose 50 $\left(7.8 \times 10^{5} \mathrm{CFU}\right.$ dose $\left.^{-1}\right)$ of $V$. anguillarum J360. Fish survival was monitored for 30 days post-challenge. The relative percent of survival (RPS) of the control and vaccinated fish was calculated using the formula: RPS $=[1-(\%$ mortality in vaccinated fish $/ \%$ mortality in control fish)] $\times 100$ [47]. 


\section{Immunization}

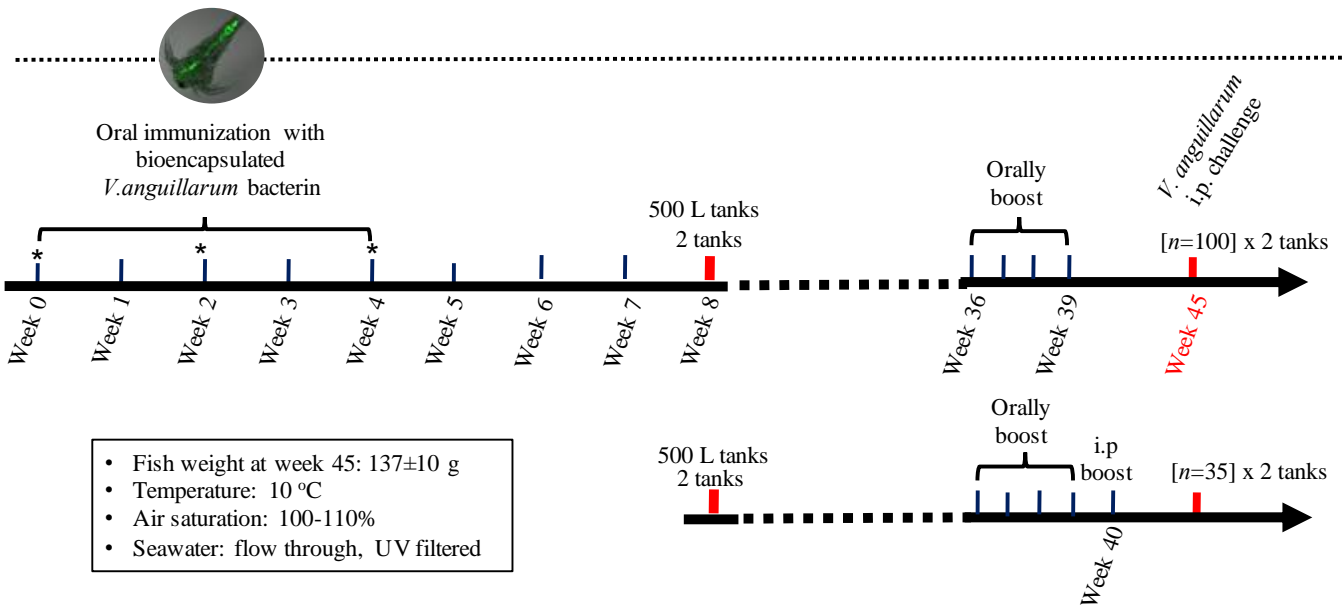

Control

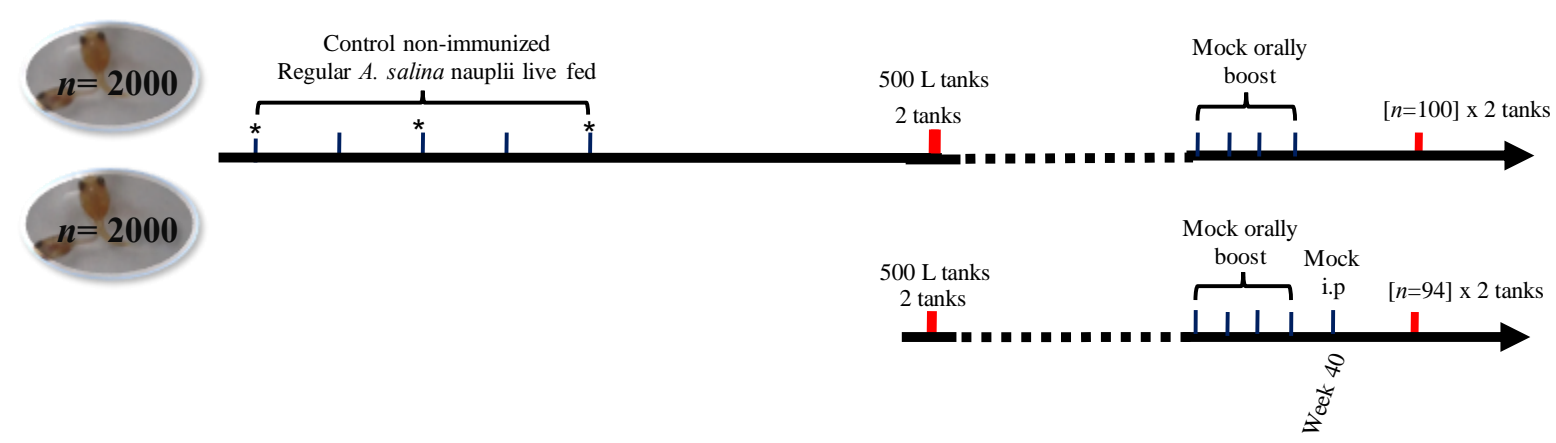

Figure 1. Immunization and challenge experimental design. Lumpfish larvae were immunized at $1 \mathrm{wph}$. At 8 wph, the fish were distributed in $500 \mathrm{~L}$ tanks. Lumpfish were boosted at $36 \mathrm{wph}$ and challenged with V. anguillarum at $45 \mathrm{wph} .{ }^{*}$ Larvae samples were collected at weeks $0,2,4$ post-immunization for RNA extraction.

\subsection{Total RNA Extraction}

RNA was extracted from the larvae pools pre-immunized ( $n=3$ individual pools of 10 larvae each), 2 wpi ( $n=3$ pools of 10 larvae each), and 4 wpi ( $n=3$ pools of 5 larvae each). RNA was also extracted from the larvae post mock immunization(control) at 2 and 4 wpi. Lumpfish larvae pools, previously flash frozen in a $1.5 \mathrm{~mL}$ RNase-free tube containing $300 \mu \mathrm{L}$ of TRIzol reagent (Invitrogen), were homogenized using a micro-tube homogenizer (ThermoFisher Scientific, Waltham, MA, USA). An additional $700 \mu \mathrm{L}$ of TRIzol was added to the tube, and the extractions were then completed following the manufacturer's instructions. The TRIzol extracted samples were then purified using the RNeasy ${ }^{\circledR}$ Mini Kit (QIAGEN, Mississauga, ON, Canada) following the manufacturer's instructions. RNA samples were treated with $2 \mathrm{U} \mathrm{mL}^{-1}$ of TURBO DNase (TURBO DNAfree $^{\mathrm{TM}} \mathrm{Kit}$, Invitrogen) following the manufacturer's instructions for the complete digestion of genomic DNA and the removal of the remaining DNase and divalent cations, such as magnesium and calcium. Purified RNA samples were quantified and evaluated for purity using a Genova Nano spectrophotometer (Jenway, Staffordshire, UK) and evaluated for integrity using $1 \%$ agarose gel electrophoresis [35]. A PCR test was conducted using the $60 S$ ribosomal protein $\mathrm{L} 32$ ( $r$ pl32) reference gene primers and the RNA as a template to rule out the presence of DNA.

\subsection{0. cDNA Synthesis and qPCR Parameters}

cDNA was synthesized in $20 \mu \mathrm{L}$ reactions from $1 \mu \mathrm{g}$ of RNA using SuperScript IV VILO Master Mix (Invitrogen) following the manufacturer's instructions. PCR amplifications were performed in $13 \mu \mathrm{L}$ reactions using 1X Power SYBR Green PCR Master Mix (Applied Biosystems, Waltham, MA, USA), $50 \mathrm{nM}$ of both the forward and reverse primers, and the 
indicated cDNA quantity. Amplifications were performed using the QuantStudio 6 Flex Real-Time PCR system (384-well format) (Applied Biosystems, Waltham, MA, USA). The real-time analysis program consisted of 1 cycle of $50{ }^{\circ} \mathrm{C}$ for $2 \mathrm{~min}, 1$ cycle of $95^{\circ} \mathrm{C}$ for $10 \mathrm{~min}, 40$ cycles of $95^{\circ} \mathrm{C}$ for $15 \mathrm{~s}$, and $60^{\circ} \mathrm{C}$ for $1 \mathrm{~min}$, with fluorescence detection at the end of each $60^{\circ} \mathrm{C}$ step and followed by dissociation curve analysis.

\subsection{1. qPCR Primer Quality Assurance Testing}

All primer pairs for the transcripts of interest (TOIs) and the endogenous control transcripts were designed and quality control $(\mathrm{QC})$ tested using the larvae RNA samples generated herein. cDNAs were synthesized from the individual pooled larvae RNA samples, including pre-immunized control, mock-immunized control (2 and $4 \mathrm{wpi}$ ), and immunized larvae ( 2 and 4 wpi). The control and immunized cDNA samples were independently pooled and used for primer quality evaluation. To calculate amplification efficiencies for each primer pair [48], standard curves were generated for both cDNA pools (control and immunized) using a 5-point 1:3 dilution series starting with cDNA representing $10 \mathrm{ng}$ of input total RNA. The reported efficiencies represent an average of the two values (Supplementary Table S1). Each primer pair was also tested to ensure that a single product was amplified and that there was no primer dimer present in the no-template control. Finally, amplicons were electrophoretically separated on $2 \%$ agarose gels and compared using a $1 \mathrm{~kb}$ plus ladder (Invitrogen) to verify that the correct size fragment was amplified.

Eighteen TOIs were well expressed in larvae, and as such, amplification efficiencies could be calculated using larvae cDNA template (see fluorescence threshold cycle $\left(\mathrm{C}_{\mathrm{T}}\right)$ values for studies 1 to 3; Supplementary Table S2). However, fourteen of these transcripts were expressed at low levels in larvae (see $C_{T}$ values for studies 4 to 6; Supplementary Table S2). For the latter TOIs, technical replicates and spacing were acceptable over the first three points of the cDNA dilution series. As the experimental input cDNA amount $(8 \mathrm{ng})$ for these TOIs lies within the first 2 dilutions, these assays were deemed acceptable for analysis in larvae. However, for these fourteen transcripts, the amplification efficiencies reported in Supplementary Table S1 and inputted into the QuantStudio Real-Time PCR Software (version 1.3) (Applied Biosystems) were those that had been previously generated for head kidney samples.

\subsection{Endogenous Control (Normalizer) Selection}

Expression levels of the TOIs were normalized to the transcript levels of the two endogenous controls. To select these endogenous controls, 5 transcripts ( $r p l 32$, elongation factor 1-alpha (ef1a), eukaryotic translation initiation factor 3 subunit D (etif3d), polyadenylatebinding protein $1 a$ (pabpc1a), and polyadenylate-binding protein $1 b$ (pabpc1b)) were analyzed. First, the $C_{T}$ values of all 27 samples in the study were measured (in duplicate) for each of these transcripts using cDNA representing $3.25 \mathrm{ng}$ of input total RNA and then analyzed using geNorm [49]. Based on this analysis, rpl32 (geNorm $\mathrm{M}=0.169$ ) and etif3d (geNorm $\mathrm{M}=0.177$ ) were selected as the two endogenous controls.

\subsection{Experimental qPCR Analyses}

To study the effects of oral immunization with the V. anguillarum bacterin bio-encapsulated in A. salina on the immunome of lumpfish larvae, expression levels of 32 TOIs with immunerelevant functional annotations were assessed (Supplementary Table S1). Individual larvae pools ( $n=27$ pools) were subjected to qPCR analyses (Figure 1 ). In the qPCR analyses, cDNA representing $3.25 \mathrm{ng}$ (study 1 to 3, see Supplementary Table S2) and 8 ng (study 3 to 6, see Supplementary Table S2) of input RNA was used as a template in the PCR reactions. The input RNA concentration was increased to 8 ng due to lower expression transcript levels in the larvae. In each qPCR study, expression levels of a given transcript were measured across two plates. On each plate, the TOIs and endogenous controls were tested in triplicate, and a notemplate control was included for every sample. A plate linker sample was also included 
to ensure that there was no plate-to-plate variability. The relative quantity (RQ) of each transcript was determined using the QuantStudio Real-Time PCR Software (version 1.3), with normalization to both the rpl32 and etif3d transcript levels and with the amplification and efficiencies incorporated. For each TOIs, the sample with the lowest normalized expression (mRNA) level was set as the calibrator sample (i.e., assigned an RQ value $=1$ ) (Supplementary Table S2). Additionally, the transcript expression levels were determined using the comparative $2^{-\Delta \Delta \mathrm{Ct}}$ method [50] with two reference genes [51] (Supplementary Table S3).

\subsection{Statistical Analysis}

All data are expressed as the mean \pm standard error (SE). Assumptions of normality and homogeneity were tested for variances. A one-way ANOVA followed by Tukey's multiple comparison post hoc test was used to determine significant differences between the survival of the control and infected groups. The Kaplan-Meier estimator was applied for the estimation of the survival fractions after the $V$. anguillarum challenges, and the log-rank test was used to identify differences between treatment groups $(p<0.0001)$. A twoway ANOVA was used to analyze the gene expression data followed by Sidak's multiple comparisons post hoc test to identify significant differences between each treatment in the control and immunized groups at each time point ( 2 weeks and 4 weeks). All statistical tests were performed using Graphpad Prism version 8.0 (Graphpad Software, USA, www.GraphPad.com (accessed on 15 June 2021)), and $p$-values $<0.05$ were considered statistically significant.

\section{Results}

\subsection{Bio-Encapsulation of V. anguillarum Bacterin in A. salina Nauplii}

We established a semi-quantitative method to estimate the levels of $V$. anguillarum bacterin bio-encapsulation in $A$. salina (Figure 2A). Autofluorescence was ruled out using $A$. salina nauplii inoculated with nutritional supplements (Ori-One and Ori-Green) (Figure 2B). Using this method, we determined that approximately $100 \%$ of the $A$. salina nauplii reached the maximum capacity for $V$. anguillarum bacterin bio-encapsulation $3 \mathrm{~h}$ post-inoculation at $20{ }^{\circ} \mathrm{C}$ in both the absence (Figure 2C) or presence (Figure 2D) of nutritional supplements. In the absence of supplements, a significant decrease in the percentage of the A. salina nauplii with $100 \%$ bio-encapsulation levels was observed $24 \mathrm{~h}$ post-inoculation, which gradually declined thereafter (Figure 2C). In the presence of nutritional supplements, a significant decrease occurred $36 \mathrm{~h}$ post-inoculation (Figure 2D). We determined that the optimal $V$. anguillarum bacterin bio-encapsulation in $A$. salina method is the presence of nutritional supplementation with a bio-encapsulation time of $3 \mathrm{~h}$ at $20{ }^{\circ} \mathrm{C}$. As we wanted to produce a bio-encapsulated vaccine batch that could be used for several days, we evaluated the stability of the $V$. anguillarum bacterin in the intestine of $A$. salina nauplii post bioencapsulation at $6^{\circ} \mathrm{C}$ (Figure S1B). This temperature was chosen as it is similar to the water temperature at which lumpfish are cultured. We determined that the bacterin concentration in A. salina nauplii remained stable for up to $6 \mathrm{~d}$ post-inoculation (Figure 2E). DTAF-labeled $V$. anguillarum bacterin bio-encapsulated in $A$. salina nauplii were then fed to lumpfish larvae and fluorescence microscopy was used to determine if the $V$. anguillarum bacterin reached the larvae gut (Figure S3). Fluorescence microscopy demonstrated the presence of the $V$. anguillarum bacterin in the gut of the lumpfish larvae after 6 and $24 \mathrm{~h}$, whereas fluorescence was not detected in the gut of lumpfish larvae who had been fed $A$. salina nauplii only (Figure 3). 
A.
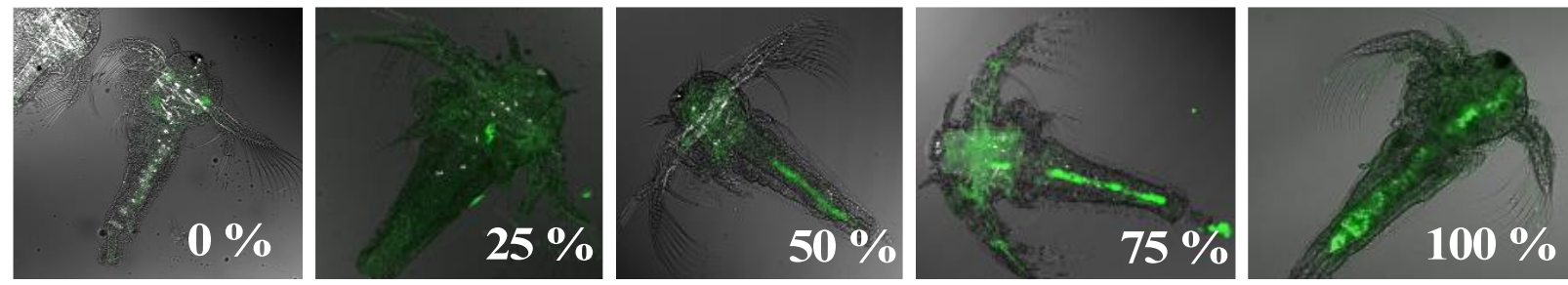

B.

A. salina nauplii fed with Ori-One
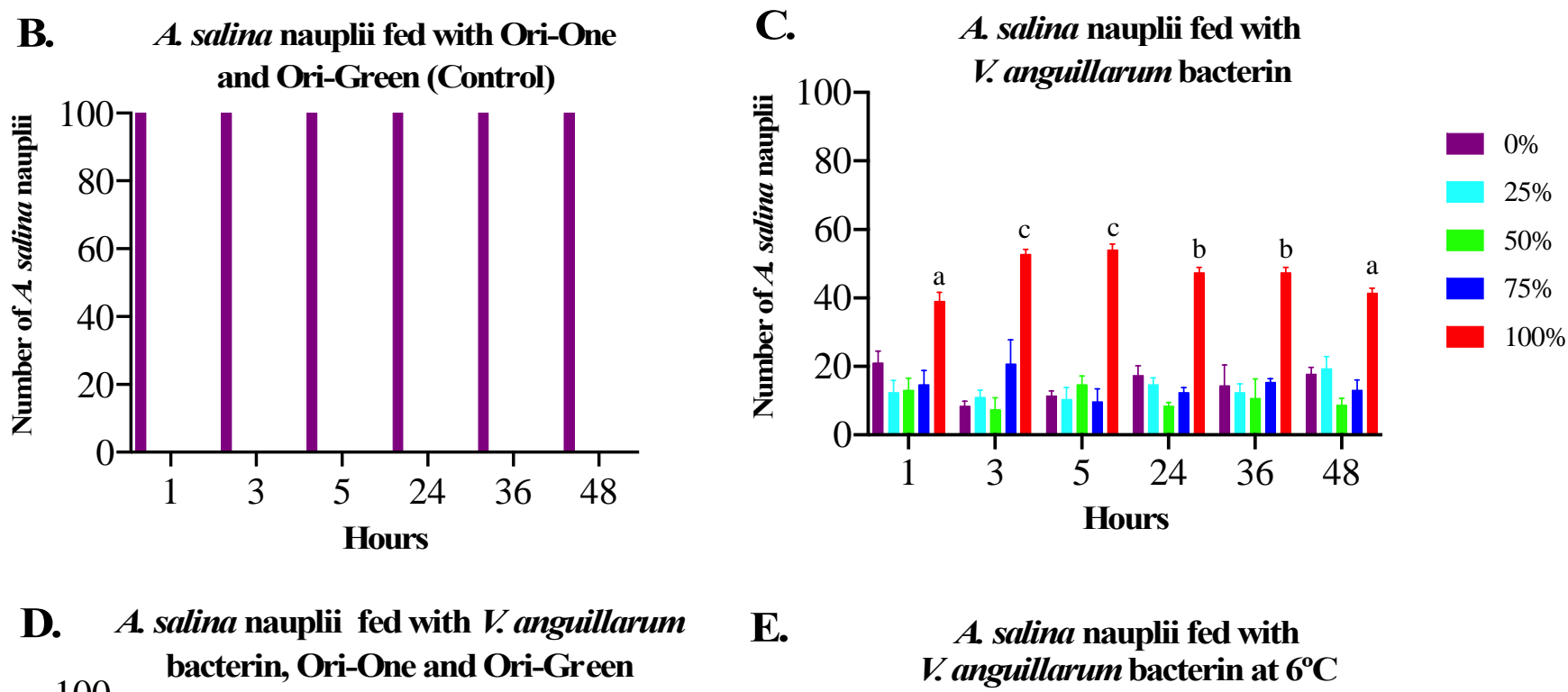

E.

A. salina nauplii fed with

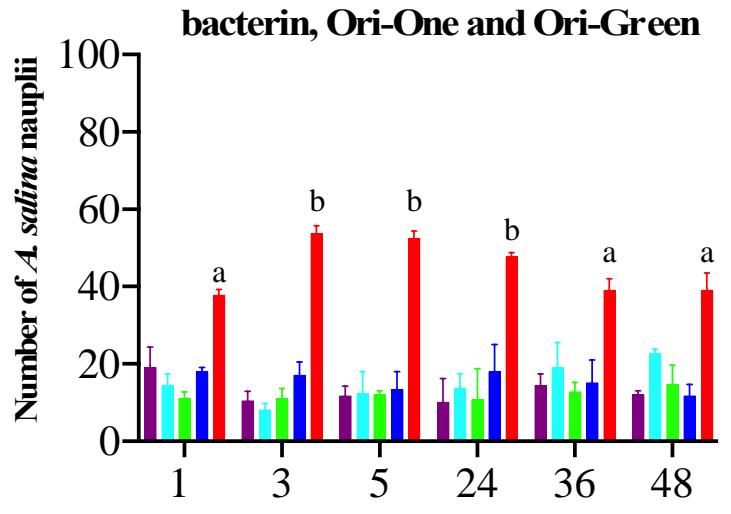

Hours

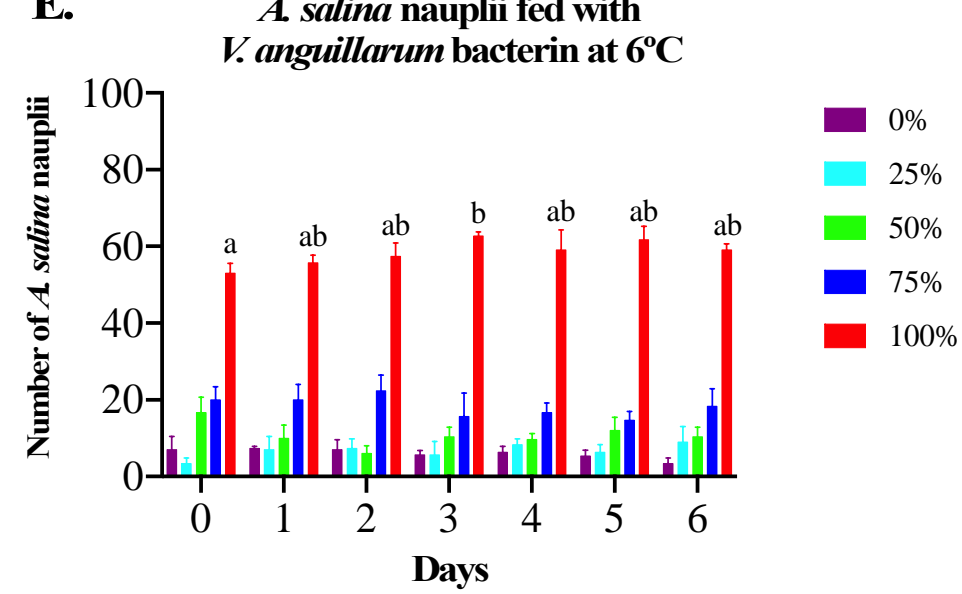

Figure 2. Optimization of $V$. anguillarum bacterin bio-encapsulation in A. salina nauplii. (A). Relative percentage of DTAFlabeled $V$. anguillarum bacterin in A. salina nauplii intestine; (B) A. salina nauplii suplemeted with dry microalgae (Ori-One and Ori-Green) as autofluorescence control. A. salina fed with commercial dry microalgae (Ori-One and Ori-Green) at $20{ }^{\circ} \mathrm{C}$; (C) V. anguillarum bacterin bio-encapsulation in A. salina nauplii at $20^{\circ} \mathrm{C}$; (D) V. anguillarum bacterin and commercial dry microalgae bio-encapsulation in A. salina nauplii at $20^{\circ} \mathrm{C}$; (E) bio-encapsulation stability at $6{ }^{\circ} \mathrm{C}$ after $3 \mathrm{~h}$ post enrichment with $V$. anguillarum bacterin at $20^{\circ} \mathrm{C}$. In all cases, different color bars represent the \% bio-encapsulation levels of the $V$. anguillarum bacterin in $A$. salina nauplii. Each value is the mean \pm SEM for 3 groups of $100 \mathrm{~A}$. salina nauplii per group. Different letters $(a, b, c)$ indicate the differences in the numbers of $A$. salina nauplii enriched with $100 \% \mathrm{~V}$. anguillarum bacterin at different time points. Means with different letters differ significantly $(p<0.05)$. Bars represent mean $\pm \mathrm{SEM}$. 


\section{Control larvae}

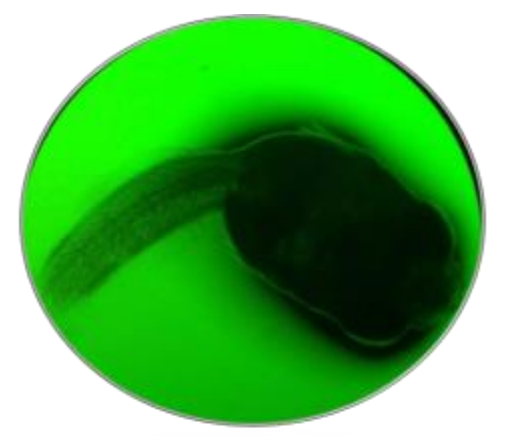

\section{Orally vaccinated larvae}

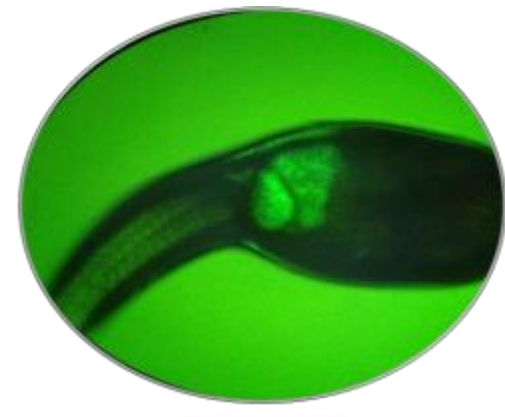

$6 \mathrm{~h}$

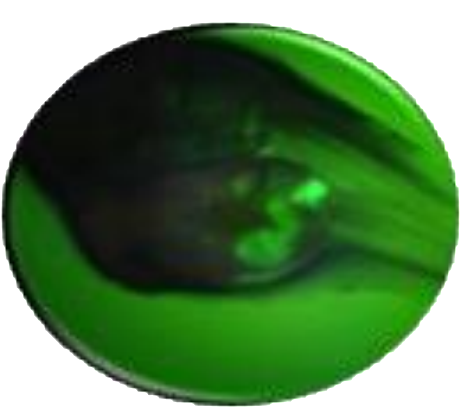

$24 \mathrm{~h}$

Figure 3. Selected images depicting the DTAF-labeled V. anguillarum bacterin bio-encapsulated in A. salina nauplii in the lumpfish gut after 6 and $24 \mathrm{~h}$, visualized using epifluorescence microscopy. Its presence is indicated by green fluorescence.

\subsection{Transcript Expression Profile of the Immunome of Orally Immunized Lumpfish Larvae}

Expression levels of the transcripts related to the innate and adaptive immune response were measured in pre-immunized larvae and at 2 and 4 wpi with the $V$. anguillarum bacterin bio-encapsulated in A. salina nauplii. The transcript expression levels were analyzed using both the $2^{-\Delta \Delta \mathrm{Ct}}$ (Figures 4 and 5) and the RQ methods (Supplementary Figures S5 and S6). Both methods showed similar results, with the exception of the statistical significance demonstrated for toll-like receptor 7 (tlr7) and immunoglobulin heavy chain b (ighb) (Figures 4-6; Supplementary Figures S5-S7). Transcript expression levels were compared statistically in orally immunized compared to control larvae at 2 and 4 wpi only. Comparisons over time could not be assessed due to developmental and considerable size differences of the larvae over time. Significant up-regulation of interleukin $8 b$ (ilsb) (Figure 4A and Figure S5A), immunoglobulin heavy chain a (igha), ighb and immunoglobulin mu heavy chain $\mathrm{c}$ (ighmc) (Figure 5A and Figure S6A), chemokines (ccl19 and ccl20) (Figure 5B and Figure S6B), cluster of differentiation 8 alpha (cd8a) and HLA class II histocompatibility antigen gamma chain (cd74) (Figure 5C and Figure S6C), interferon-gamma (ifng) (Figure 6 and Figure S7), and ATPdependent RNA helicase $\lg p 2(\lg p 2)$ (Figure 6 and Figure S7) occurred at 2 wpi. Significant upregulation of interleukin 10 (il10) occurred at 4 wpi (Figure 4A and Figure S5A). Significant downregulation of lymphocyte antigen 6 family member G6F (ly6g6f) (Figure 6 and Figure S7) and $c c l 20$ (Figure 6B and Figure S6B) occurred at 2 and 4 wpi, respectively. There were no significant differences in the expression levels of the remaining transcripts at either time point. 
$\mathbf{A}$

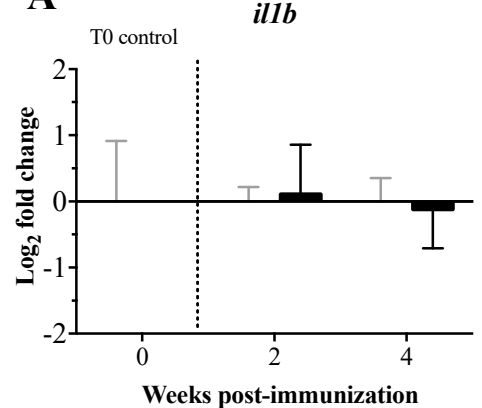

D
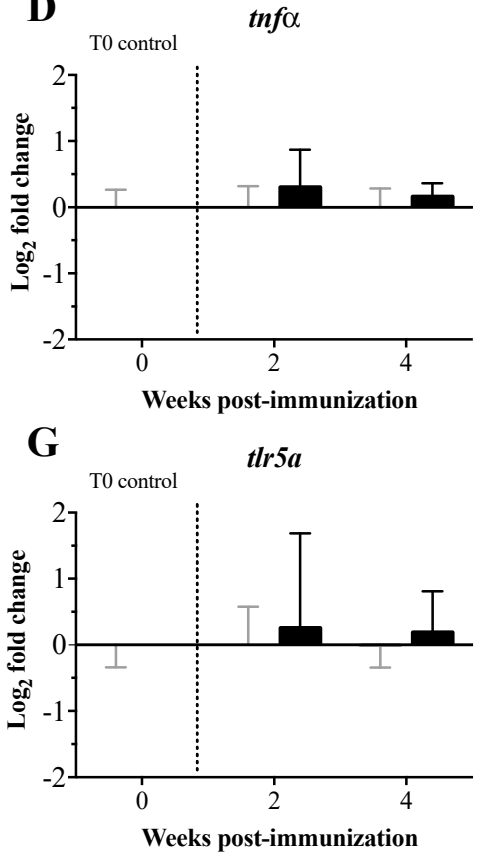

B
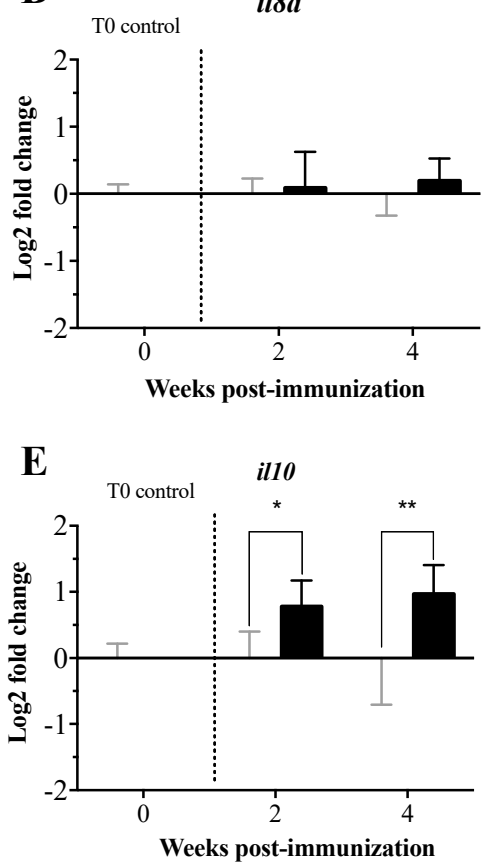

H ttr5b

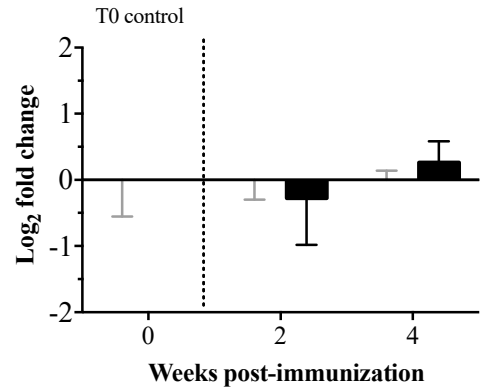

C ilsb

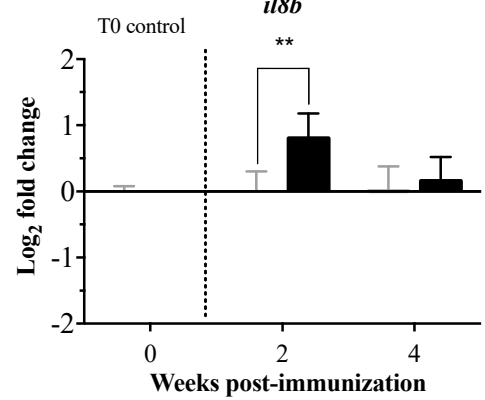

$\mathbf{F}$

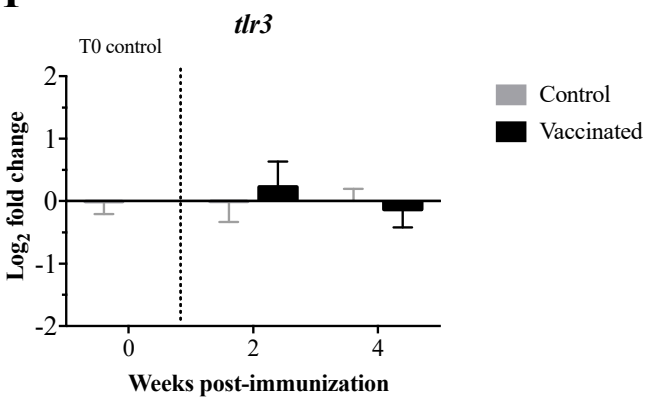

I

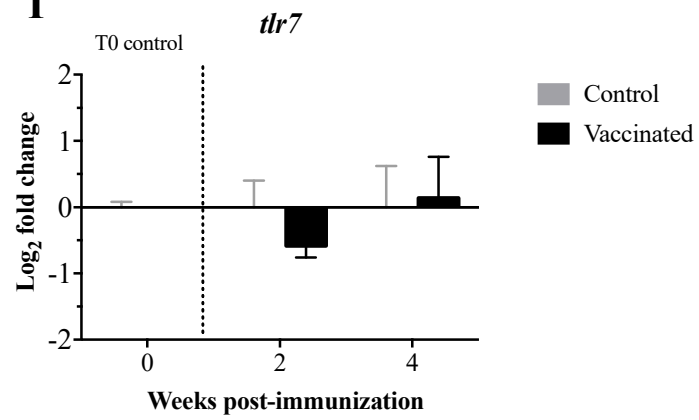

Figure 4. Transcript expression levels of cytokines and toll-like receptors in lumpfish larvae orally immunized with the $V$. anguillarum bacterin bio-encapsulated in A. salina nauplii. (A-E). Cytokines; (F-I). Toll-like receptors. Transcript expression levels were assessed pre-immunization (T0 control, $n=3$ individual pools of 10 larvae each), $2 \mathrm{wpi}$ ( $n=3$ pools of 10 larvae each), and 4 wpi ( $n=3$ pools of 5 larvae each). Time point controls post-mock immunization were collected in a similar fashion at 2 and 4 wpi. Relative expression was calculated using the $2^{(-\Delta \Delta C t)}$ method and normalized using $\log _{2}$; etif3d and rpl32 were used as endogenous controls. A two-way ANOVA test, followed by the Sidak multiple comparisons post hoc test was used to assess significant differences between the treatments (control and vaccinated) at each individual time point. Asterisks $\left(^{*}\right)$ represent significant differences $\left({ }^{*} p<0.05,{ }^{* *} p<0.01\right)$. 

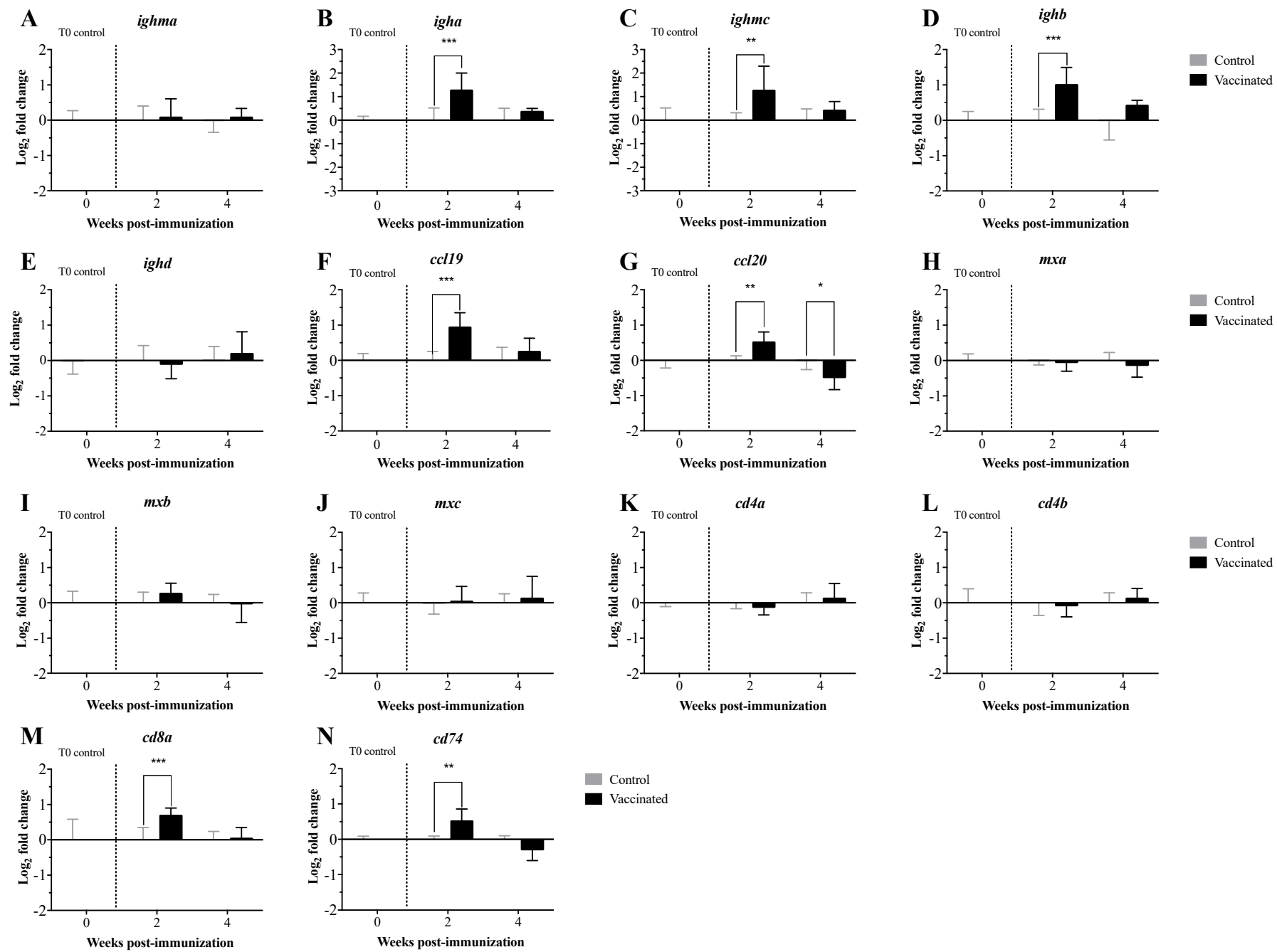

Figure 5. Transcript expression levels of immunoglobulin heavy locus genes, cytokine CC genes and interferon-induced GTP-binding proteins genes, and cluster of differentiation genes in lumpfish larvae orally immunized with the V. anguillarum bacterin bio-encapsulated in A. salina nauplii (A-E). Immunoglobulin heavy locus genes (F-J). Cytokine CC genes and interferon-induced GTP-binding proteins genes $(\mathbf{K}-\mathbf{N})$. Cluster of differentiation genes. Transcript expression levels were assessed pre-immunization (T0 control, $n=3$ individual pools of 10 larvae each), 2 weeks post-immunization ( $n=3$ pools of 10 larvae each), and 4 weeks post-immunization ( $n=3$ pools of 5 larvae each). Time point controls post-mock immunization were collected in a similar fashion to those collected at weeks 2 and 4 . Relative expression was calculated using the $2^{(-\Delta \Delta C t)}$ method and normalized using $\log _{2}$; etif3d and rpl32 were used as endogenous controls. A two-way ANOVA test followed by the Sidak multiple comparisons post hoc test were used to assess significant differences between the treatments (control and vaccinated) at each individual time point. Asterisks $\left({ }^{*}\right)$ represent significant differences $\left({ }^{*} p<0.05,{ }^{* *} p<0.01,{ }^{* * *} p<0.001\right)$. 

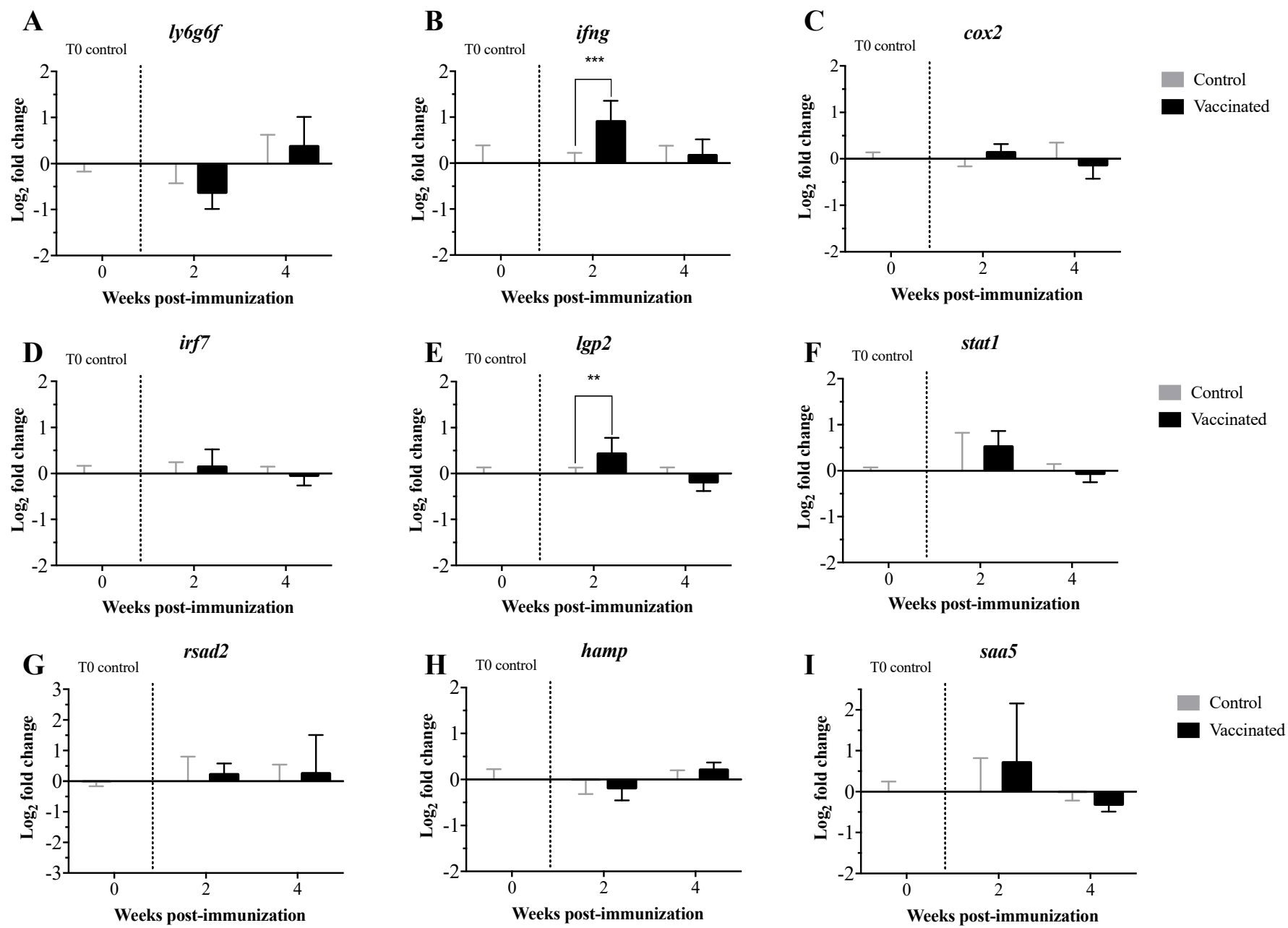

Figure 6. Transcript expression levels of other immune-related genes in lumpfish larvae orally immunized with the $V$. anguillarum bacterin bio-encapsulated in A. salina nauplii (A-I). Transcript expression levels were assessed pre-immunization (T0 control, $n=3$ individual pools of 10 larvae each), 2 weeks post-immunization ( $n=3$ pools of 10 larvae each), and 4 weeks post-immunization ( $n=3$ pools of 5 larvae each). Time point controls post-mock immunization were collected in a similar fashion to those collected at weeks 2 and 4 . Relative expression was calculated using the $2^{(-\Delta \Delta C t)}$ method and normalized using $\log _{2}$; etif3d and rpl32 were used as endogenous controls. A two-way ANOVA test followed by the Sidak multiple comparisons post hoc test were used to assess significant differences between the treatments (control and vaccinated) at each individual time point. Asterisks $\left({ }^{*}\right)$ represent significant differences $\left({ }^{* *} p<0.01,{ }^{* * *} p<0.001\right)$.

\subsection{Vaccine Challenge}

Immunized lumpfish were challenged at 45 wpi with 7 times the $\mathrm{LD}_{50}$ dose for $V$. anguillarum $\mathrm{J} 360\left(7.8 \times 10^{5} \mathrm{CFU}\right.$ dose $\left.^{-1}\right)$ (Figure 1). Mortality in lumpfish who had been orally mock immunized as larvae and then mock-orally boosted as juveniles started at 3 days post-challenge, with $100 \%$ mortality by day 10 post-challenge. Mortality in lumpfish that had been orally immunized as larvae and then orally boosted as juveniles was delayed and started at 3 days post-challenge, with a final RPS of 2\% (Figure 7A). Mortality in lumpfish that had been mock orally immunized as larvae and then both mock orally and i.p. boosted as juveniles started at 7 days post-challenge, with $100 \%$ mortality by 20 days post-challenge (Figure 7B). Lumpfish that had been orally immunized as larvae and then both orally and i.p. boosted as juveniles survived the i.p. challenge with V. anguillarum, with a RPS of $76.5 \%(p<0.0001)$ (Figure 7B). 
A

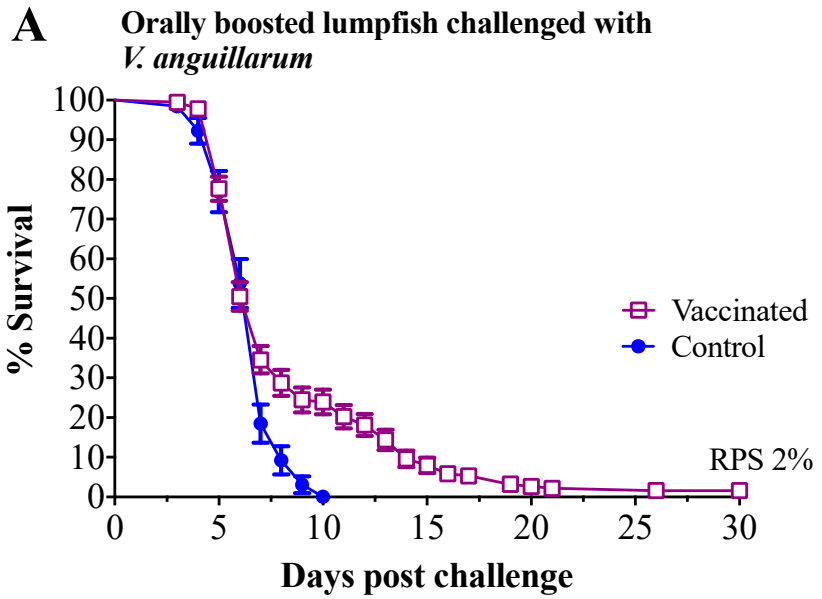

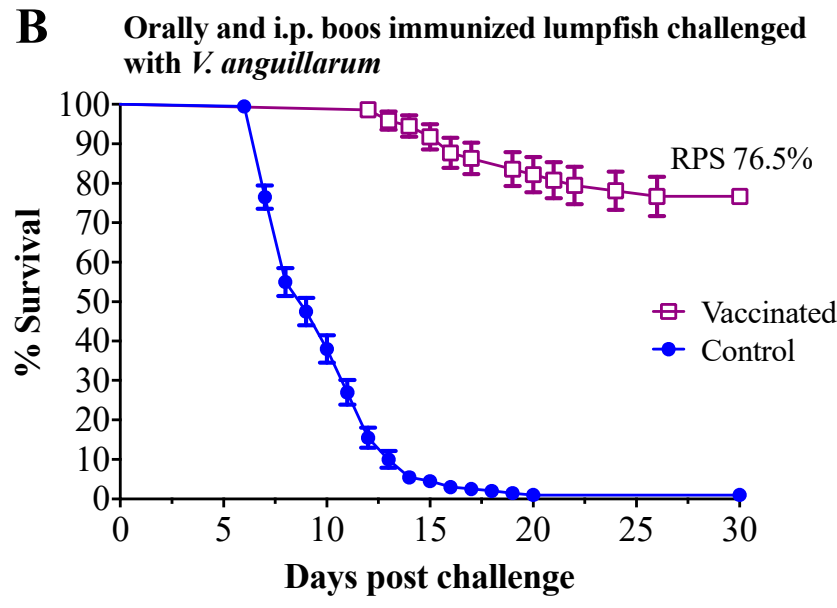

Figure 7. Cumulative survival rate of orally and i.p. immunized lumpfish after i.p. challenge with $V$. anguillarum $\left(7.8 \times 10^{5} \mathrm{CFU}\right.$ dose $\left.{ }^{-1}\right) .(\mathrm{A})$ Survival (\%) of orally immunized and orally boosted lumpfish after V. anguillarum challenge. Lumpfish were orally immunized as larvae and then orally boosted as juveniles. Control groups were mock-vaccinated using the same inoculation route. After 45 weeks post-initial immunization, the animals were then i.p. challenged; each treatment consisted of two tanks (see Figure 1). (B) Survival of orally immunized and i.p. boosted lumpfish. Lumpfish were orally immunized as larvae and then orally boosted as juveniles (see Figure 1). Control groups were mock-vaccinated using the same inoculation route. After 45 weeks post-initial immunization, the animals were then i.p. challenged; Each treatment consisted of two tanks (see Figure 1). Survival was assessed for 30 days. RPS: relative percentage survival; $p<0.0001$.

\section{Discussion}

Vibriosis is one of the most common bacterial diseases affecting lumpfish aquaculture [39]. As mentioned previously, immunization of fish at an early age with a needle-free vaccine and with minimal stress during immunization is the ideal vaccine delivery method for finfish aquaculture [30]. However, the effectiveness of bath and oral inactivate vaccine delivery to small fish or larvae has been evaluated with varied results [52]. Commercial bath vaccines have been used in lumpfish with low effectiveness against local $V$. anguillarum isolates [28]. However, the efficacy of an orally administered vaccine in lumpfish during the early-life stages remains unknown. Here, we evaluated the efficacy of an orally delivery $V$. anguillarum bacterin bio-encapsulated in A. salina nauplii in lumpfish larvae. The molecular immune response to oral immunization was evaluated in larvae by qPCR. Approximately 9 months after the initial oral immunization, lumpfish were then either orally or both orally and i.p. boosted, and the effectiveness of the vaccines was evaluated by assessing the RPS after a lethal i.p. V. anguillarum challenge.

First, we evaluated the $V$. anguillarum bacterin uptake in $A$. salina nauplii and, thereafter this bio-encapsulated bacterin, in the gut of lumpfish larvae. Our observations indicated that the $V$. anguillarum bacterin was fully bio-encapsulated by the $A$. salina nauplii after $3 \mathrm{~h}$ and was maintained for at least $6 \mathrm{~d}$ at $6{ }^{\circ} \mathrm{C}$ (Figure 2). Similar results were observed by Campbell et al. [32], where the $V$. anguillarum bacterin showed maximum bio-encapsulation after $1 \mathrm{~h}$ or $2 \mathrm{~h}$ using $1.5 \times 10^{7} \mathrm{CFU} \mathrm{mL}{ }^{-1}$ or $1.5 \times 10^{6}$ cells $\mathrm{mL}^{-1}$, respectively. Vaccine bio-encapsulation in A. salina nauplii protects the antigens from the intestinal tract of the fish and facilitates the recognition of the antigens using the macrophages in the mucosal layer of the hindgut [53]. The effectiveness of protecting the antigen from gastrointestinal digestion and its delivery to the hindgut of fish larvae has been demonstrated in previous studies $[33,53]$. Here, we confirmed the presence of the $V$. anguillarum bacterin in the $A$. salina nauplii and in the gut of fish larvae $6 \mathrm{~h}$ post-oral immunization (Figure 3). These results validated the internalization of the $V$. anguillarum bacterin in the lumpfish gut.

The expression profiles of 32 TOIs related to innate and adaptive immunity were evaluated in larvae pre-immunization and at 2 and 4 wpi. In pre-immunized larvae, we did not see any expression of the TOIs, which was expected. When considering 
orally immunized compared to larvae who had been orally mock immunized at 2 and $4 \mathrm{wpi}$, there were no significant differences in the levels of pro-inflammatory cytokines (tnfa, il1b, ilsa; Figure 4A and Figure S6A), toll-like receptors ( $t \operatorname{lr} 3, t \operatorname{tr} 5 a, t l r 5 b$; Figure 4B and Figure $\mathrm{S6B}$ ), immunoglobulin heavy chain transcripts (ighma, ighd; Figure 5A and Figure S7A), interferon-induced effectors ( $m x a, m x b, m x c$; Figures $5 \mathrm{~B}$ and $7 \mathrm{~B})$, cluster of differentiation transcripts ( $c d 4 a, c d 4 b$; Figure 5C and Figure S7C), or other immune-related transcripts (cox2, irf7, lgp2, stat1, rsad2, hamp, saa5; Figure 6 and Figure S8). In contrast, levels of il8b, igha, ighmc, ighb, ccl19, ccl20, cd8a, cd74, ifng, and lgp 2 were significantly upregulated, and levels of $l y 6 g 6 f$ and $t l r 7$ were significantly downregulated at 2 wpi (Figures $4 \mathrm{~A}, 5$ and 6 , Figures S6A, S7 and S8). Levels of il10 were significantly upregulated, and levels of $c c l 20$ were significantly downregulated at 4 wpi (Figures $4 \mathrm{~A}$ and 5B, Figures S6A and S7B). These results indicate that $35 \mathrm{~d}$ old lumpfish larvae are not highly immune stimulated by oral immunization, suggesting that the interaction between the lymphoid tissues and the vaccine was not enough to trigger adaptive immune protection.

$i l 8$ and ifng play important roles in the recruitment of monocytes and neutrophils to sites of inflammation. Whereas illo acts as anti-inflammatory cytokine and as such, plays a crucial role in the regulation of the inflammatory response [54]. Although there are studies on the expression of il8 and il10 in fish, the role of these interleukins in the early developmental stages of lumpfish is still unknown. In the current study, in orally immunized larvae compared to larvae who had been orally mock immunized, il 8 and ifng were significantly upregulated at $2 \mathrm{wpi}$, il10 significantly upregulated at 4 wpi (Figures $4 \mathrm{~A}, 5$ and 6; Figures S6 and S8A). Similar expression profiles for ifng and il10 have been observed in Atlantic salmon that had been infected with the salmonid alphavirus subtype-3 (SAV3) [55] or immunized with the A. salmonicida vaccine [56]. $\operatorname{lgp} 2$ is a member of the RLR family that participates in the recognition of viral RNA pathogen-associated molecular patterns (PAMPs) in the cytoplasm and induces the synthesis of ifng [57-60]. Similarly, our results showed that $\lg p 2$ and ifng were significantly upregulated at 2 wpi (Figure 6 and Figure S8). The results suggest that the oral immunization of lumpfish larvae triggers an innate immune response that is later regulated via the canonical anti-inflammatory cytokine il10.

TLRs play an important role in early innate and adaptive immunity by detecting PAMPs in bacteria and viruses [61-63]. TLRs activate the transcription factor NF- $\mathrm{kB}$, resulting in the production of several pro-inflammatory cytokines such as il1b, tnfa, ils, il10, il6, il12, il17, ifng, and the tumour necrosis factor (tnf) [64,65]. Expression levels of $t l r 3, t l r 5$, and $t l r 7$ were not significantly different in orally immunized compared to larvae who had been orally mock immunized at either time point (Figure 4B), however $t l r 7$ was significantly downregulated at 2 wpi in the RQ statistical analysis (Figure S6B). These results suggest that the vaccine does not induce a full immune response in larvae.

ly6g6f is a member of the superfamily lymphocyte antigen-6 (Ly6)/urokinase-type plasminogen activator receptor (UPAR) [66]. Ly6/uPAR proteins have functions in cell proliferation, migration, cell-cell interaction, immune cell maturation, macrophage activation, T lymphocyte development, differentiation, and cytokine production [67-69]. The function of $\operatorname{ly} 6 g 6 f$ in fish is not yet defined, and in this study, the expression of $l y 6 g 6 f$ was significantly downregulated at 2 wpi in lumpfish larvae (Figure 6 and Figure S8). These results agree with the low level of immune protection.

The igh (immunoglobulin heavy locus) encodes the IgM heavy chains, and these loci have been characterized in several fish species, including fugu, rainbow trout, zebrafish, and Atlantic salmon [70-72]. It has been established that igh plays a role during the adaptive immune response by recognizing foreign antigens for phagocytosis, and the complement system [73]. Here, we found that igha, ighd, and ighmc expression were significantly upregulated in orally immunized compared to larvae who had been orally mock immunized at 2 wpi (Figure 5A and Figure S7A). These results suggest the oral immunization of larvae triggers some level of an adaptive immune response, but it seems insufficient to trigger memory immune protection. 
ccl19 is a chemokine known to orchestrate the migration of dendritic cells (DCs) and T cells into lymphoid tissue or vaccination sites and is also involved in immune tolerance and inflammatory responses [74,75]. ccl20 attracts lymphocytes and DCs towards epithelial cells to mucosal immune sites under inflammatory conditions [76]. In orally immunized compared to larvae who had been orally mock immunized, there was a significant increase in levels of ccl19 and ccl20 at 2 wpi, while there was a significant decrease in ccl20 levels at 4 wpi (Figure 5B and Figure S7B). These results aligned with the expression patterns of other transcripts evaluated here, supporting the idea that the lumpfish larvae did respond to the oral immunization.

CD4 (a classical marker of T helper cells) and CD8 (a marker of cytotoxic lymphocytes) are polypeptides that play an important role in signal transduction and the activation of T-helper cells and cytotoxic T cells, respectively [77]. We found that $c d 8$ was significantly upregulated in orally immunized compared to larvae who had been orally mock immunized at 2 wpi (Figure 5C and Figure S7C). However, $c d 4$ was not significantly dysregulated. These results suggest that CD8 cellular-mediated adaptive immunity, but not the CD4 response, was activated in lumpfish larvae aligning with the lack of immune protection triggered by the oral immunization (Figure 7A).

CD74 is the MHC class II-associated invariant chain, which plays a role in antigen presentation [78,79]. CD4 and CD74 lost their original functions in anglerfish (Lophius piscatorius) and Atlantic cod (Gadus morhua) [80-83]. Here, we found that these transcripts are present in lumpfish, and although $c d 74$ was upregulated in orally immunized compared to larvae who had been orally mock immunized at 2 wpi, $c d 4 a$ and $c d 4 b$ were not (Figure 5C and Figure S7C). These results revealed that oral immunization in lumpfish larvae triggers a partial adaptive immune response.

The lumpfish larvae were vaccinated after the yolk sac was absorbed, after which the larvae exhibited an active feeding behavior. Although there is no literature about the immunity of lumpfish larvae, it is well known that lumpfish larvae are more mature and active than other marine fish [84]. It has also been shown that the main immune organs of lumpfish develop after hatching [85]. These reports, in addition to our current results, suggest that lumpfish larvae are immune competent, and antigens need to be delivered across the epithelia to trigger full immunity. The transcript expression levels (Figures 4-6) also indicated that lumpfish larvae are immune stimulated by oral immunization, but not enough to trigger immune protection. For instance, the expression of ilsb, ilo, igha, ighmc, $i g h b, c d 8$, and $c 74$ was upregulated in orally immunized larvae (Figures 4-6). It seems that oral immunization with $V$. anguillarum bacterin in lumpfish larvae triggered Th1-like immune response and cellular immunity, which is related to $i l 10$ and $c d 8$ upregulation. This is the first study on lumpfish larvae molecular immunity and provides novel knowledge and a baseline to study the ontogeny of the immune system in lumpfish.

The effectiveness of vaccination in fish depends on the delivery, vaccine design, and the fish species. For instance, mortality in lumpfish bath immunized and i.p. boosted with a commercial polyvalent formalin-inactivated $V$. anguillarum $\mathrm{O} 1$ and $\mathrm{O} 2$ vaccine was only delayed in an i.p. challenge using V. anguillarum [28]. Similar to our current results, a commercial bivalent whole-cell $V$. anguillarum $\mathrm{O} 1$ and $\mathrm{O} 2$ vaccine delivered by immersion and followed by an i.p. boost immunization in European sea bass (Dicentrarchus labrax) conferred approximately $99 \%$ survival against a $V$. anguillarum i.p. challenge [86]. In this study, we observed that lumpfish orally immunized as larvae and then orally boosted as juveniles did not survive the $V$. anguillarum i.p. challenge (Figure 7A). Nevertheless, we determined that oral vaccination delayed mortality in lumpfish challenged with $V$. anguillarum, suggesting that the oral vaccination did stimulate fish immunity, but not enough to confer protection. Similar results were found in salmonids orally immunized against Yersinia and $V$. anguillarum, where oral immunization conferred no or low immunity to juvenile immunized fish [87-90]. In contrast, lumpfish orally immunized as larvae and then both orally and i.p. boosted as juveniles showed a significant RPS (76.5\%) to the $V$. anguillarum i.p. challenge (Figure 7B). This suggests that the orally administered 
vaccines were not reaching the deep lymphoid tissues, either in the larvae or juvenile fish, and as such, oral immunization was not effective in contrast to the i.p. delivered vaccine. Therefore, it is suggested that inactivated $V$. anguillarum vaccines for lumpfish should be administered using the i.p. route to confer acceptable levels of immune protection.

\section{Conclusions}

Oral immunization of lumpfish larvae using bio-encapsulated bacterin demonstrated that it reached the gut and immune, stimulating the fish larvae. However, oral immunization did not trigger an evident adaptive immune response, even after oral boost immunization. $V$. anguillarum bacterin that had been orally administered delayed mortality and did not confer protection against the i.p. V. anguillarum. In contrast, i.p. immunization conferred significant immune protection. These results suggest the need for oral vaccines that have the capability of crossing the epithelium and reaching the deep lymphoid tissues to trigger immune protection.

Supplementary Materials: The following are available online at https:/ / www.mdpi.com/article / 10.3390/vaccines9080819/s1, Figure S1: Experimental design for optimization of V. anguillarum bacterin bio-encapsulation in A. salina nauplii, Figure S2: Lumpfish culture conditions and embryonic development, Figure S3: Oral immunization of lumpfish larvae with the DTAF-labeled V. anguillarum bacterin bio-encapsulated in Artemia nauplii, Figure S4: V. anguillarum bacterin bio-encapsulation in A. salina nauplii for industrial application, Figure S5: Transcript expression levels of cytokines (A) and toll-like receptors (B) in lumpfish larvae orally immunized with the $V$. anguillarum bacterin bioencapsulated in A. salina nauplii, Figure S6: Transcript expression levels of immunoglobulin heavy locus genes (A), cytokine CC genes and interferon-induced GTP-binding proteins (B), and cluster of differentiation genes $(\mathrm{C})$ in lumpfish larvae orally immunized with the $V$. anguillarum bacterin bio-encapsulated in A. salina nauplii, Figure S7: Transcript expression levels of other immune-related genes in lumpfish larvae orally immunized with the V. anguillarum bacterin bio-encapsulated in $A$. salina nauplii, Table S1: Sequences of primer pairs used in qPCR analyses of transcript expression levels in lumpfish (Cyclopterus lumpus) larvae, Table S2: Ct, $\Delta \mathrm{Ct}$, and RQ values of transcript expression levels of immune-related transcripts in lumpfish (Cyclopterus lumpus) larvae orally immunized with the $V$. anguillarum bacterin bio-encapsulated in A. salina nauplii, Table S3: Conversion and normalization of $\mathrm{Ct}$ values using the $2^{(-\Delta \Delta \mathrm{Ct})}$ method.

Author Contributions: Conceptualization, M.D., J.S., D.B. and J.W.; methodology, M.D., T.C., A.H., I.V., H.G., S.K., J.R.H., J.M., D.B. and J.S.; investigation, M.D., J.M., D.B., J.R.H., J.W. and J.S.; writingoriginal draft, M.D. and J.S.; resources: J.S., D.B. and J.W.; writing-review and editing, M.D., T.C., I.V., H.G., S.K., J.M., D.B., J.W. and J.S.; visualization, M.D. and J.S.; supervision, J.S. and J.W.; funding acquisition, J.S., J.W. and D.B. All authors have read and agreed to the published version of the manuscript.

Funding: Research funding was provided by the Ocean Frontier Institute through an award from the Canada First Research Excellence Fund (sub-module J3), the Vietnam International Education Development (VIED) fellowship, the Government of Newfoundland and Labrador, Department of Fisheries and Land Resources, NSERC-Discovery grant (RGPIN-2018-05942), and the Atlantic Fisheries Fund, Canada.

Institutional Review Board Statement: Animal protocols \#18-01-JS, \#18-03-JS (21 January 2018), and biohazard licence L-01 were reviewed and approved by the Institutional Animal Care Committee (https:/ / www.mun.ca/research/about/acs/acc/) (accessed on 15 June 2021) following the Canadian Council of Animal Care guidelines (https:/ / www.ccac.ca/) (accessed on 15 June 2021).

Informed Consent Statement: Not applicable.

Data Availability Statement: Not applicable.

Acknowledgments: We thank the staff at the Cold-Ocean Deep-Sea Research Facility (CDRF) and the Joe Brown Aquaculture Research Building (JBARB) for their expert technical assistance with the fish assays. Primers for qPCR analysis were designed and quality-tested, and qPCR were data generated at the Functional Genomics and Molecular Biology laboratory, Aquatic Research Cluster, CREAIT Network, Memorial University of Newfoundland. 
Conflicts of Interest: The authors declare no conflict of interest.

\section{References}

1. Costello, M.J. The global economic cost of sea lice to the salmonid farming industry. J. Fish Dis. 2009, 32, 115-118. [CrossRef] [PubMed]

2. Fast, M.D. Fish immune responses to parasitic copepod (namely sea lice) infection. Dev. Comp. Immunol. 2014, 43, 300-312. [CrossRef]

3. Aaen, S.M.; Helgesen, K.O.; Bakke, M.J.; Kaur, K.; Horsberg, T.E. Drug resistance in sea lice: A threat to salmonid aquaculture. Trends Parasitol. 2015, 31, 72-81. [CrossRef]

4. Overton, K.; Barrett, L.T.; Oppedal, F.; Kristiansen, T.S.; Dempster, T. Sea lice removal by cleaner fish in salmon aquaculture: A review of the evidence base. Aquacult. Environ. Interact. 2020, 12, 31-44. [CrossRef]

5. Brooks, K.M. Considerations in developing an integrated pest management programme for control of sea lice on farmed salmon in Pacific Canada. J. Fish Dis. 2009, 32, 59-73. [CrossRef] [PubMed]

6. Brooker, A.J.; Papadopoulou, A.; Gutierrez, C.; Rey, S.; Davie, A.; Migaud, H. Sustainable production and use of cleaner fish for the biological control of sea lice: Recent advances and current challenges. Vet. Rec. 2018, 183, 383. [CrossRef]

7. Treasurer, J.W. A review of potential pathogens of sea lice and the application of cleaner fish in biological control. Pest Manag. Sci. 2002, 58, 546-558. [CrossRef] [PubMed]

8. Boyce, D.; Ang, K.P.; Prickett, R. Cunner and lumpfish as cleaner fish species in Canada. In Cleaner Fish Biology and Aquaculture Applications; Treasurer, J.W., Ed.; 5M Publishing Ltd.: Sheffield, UK, 2018.

9. Umasuthan, N.; Valderrama, K.; Vasquez, I.; Segovia, C.; Hossain, A.; Cao, T.; Gnanagobal, H.; Monk, J.; Boyce, D.; Santander, J. A novel marine pathogen isolated from wild cunners (Tautogolabrus adspersus): Comparative genomics and transcriptome profiling of Pseudomonas sp. strain J380. Microorganisms 2021, 9, 812. [CrossRef]

10. Monk, J.; Boyce, D.L.; Ang, K.P.; George, S.; Tucker, D.; Jeannot, K.; Fry, J.; Gianasi, B.; Hickey, S.; O’Brien, N. Cleaner fish research and production in Newfoundland. Bull. Aqaucult. Assoc. Can. 2016, 2, 39-45.

11. Charmley, K.J. Habitat selection by two species of cleaner fishes that may be beneficial in removing sea lice from cultured salmon. SURG J. 2019, 11. [CrossRef]

12. Marcos-Lopez, M.; Donald, K.; Stagg, H.; McCarthy, U. Clinical Vibrio anguillarum infection in lumpsucker Cyclopterus lumpus in Scotland. Vet. Rec. 2013, 173, 319. [CrossRef]

13. Imsland, A.K.; Reynolds, P.; Eliassen, G.; Hangstad, T.A.; Foss, A.; Vikingstad, E.; Elvegård, T.A. The use of lumpfish (Cyclopterus lumpus L.) to control sea lice (Lepeophtheirus salmonis krøyer) infestations in intensively farmed atlantic salmon (Salmo salar L.). Aquaculture 2014, 424, 18-23. [CrossRef]

14. Whittaker, B.A.; Consuegra, S.; Garcia de Leaniz, C. Genetic and phenotypic differentiation of lumpfish (Cyclopterus lumpus) across the North Atlantic: Implications for conservation and aquaculture. PeerJ 2018, 6, e5974. [CrossRef]

15. Toffan, A.; De Salvador, M.; Scholz, F.; Pretto, T.; Buratin, A.; Rodger, H.D.; Toson, M.; Cuenca, A.; Vendramin, N. Lumpfish (Cyclopterus lumpus, Linnaeus) is susceptible to viral nervous necrosis: Result of an experimental infection with different genotypes of Betanodavirus. J. Fish Dis. 2019, 42, 1667-1676. [CrossRef] [PubMed]

16. Rueness, E.; Berg, P.R.; Gulla, S.; Halvorsen, K.; Järnegren, J.; Malmstrøm, M.; Mo, T.A.; Rimstad, E.; de Boer, H.; Eldegard, K.; et al. Assessment of The Risk to Norwegian Biodiversity from Import of Wrasses and Other Cleaner Fish for Use in Aquaculture. Norwegian Scientific Committee for Food and Environment (VKM). 2019, pp. 2535-4019. Available online: https:/ /vkm.no/download/18.22fe061816d90c026b4a890d/1570782153468/Assessment\%20of\%20the\%20risk\%20to\% 20Norwegian\%20biodiversity\%20from \%20import \%20of\%20wrasses $\% 20$ and $\% 20$ other $\% 20$ cleaner $\% 20$ fish $\% 20$ for $\% 20$ use $\% 20$ in\%20aquaculture.pdf (accessed on 15 June 2021).

17. Powell, A.; Treasurer, J.W.; Pooley, C.L.; Keay, A.J.; Lloyd, R.; Imsland, A.K.; Garcia de Leaniz, C. Use of lumpfish for sea-lice control in salmon farming:challenges and opportunities. Rev. Aquac. 2017, 10, 1-20. [CrossRef]

18. NDF Fisheries. Norwegian Directorate for Fisheries. 2019. Available online: https://www.fiskeridir.no/English/Aquaculture/ Statistics/Cleanerfish-Lumpfish-and-Wrasse (accessed on 15 June 2021).

19. Foss, A.; Imsland, A.K.D.; Roth, B.; Nytrø, A.V. Catch me if you can: How to recapture lumpfish using light as an attractant. Aquac. Eng. 2020, 90, 102074. [CrossRef]

20. Bolton-Warberg, M. An overview of cleaner fish use in Ireland. J. Fish Dis. 2018, 41, 935-939. [CrossRef] [PubMed]

21. Ronneseth, A.; Haugland, G.T.; Colquhoun, D.J.; Brudal, E.; Wergeland, H.I. Protection and antibody reactivity following vaccination of lumpfish (Cyclopterus lumpus L.) against atypical Aeromonas salmonicida. Fish Shellfish Immunol. 2017, 64, 383-391. [CrossRef] [PubMed]

22. Ellul, R.M.; Bulla, J.; Brudal, E.; Colquhoun, D.; Wergeland, H.; Ronneseth, A. Protection and antibody reactivity in lumpsucker (Cyclopterus lumpus L.) following vaccination against Pasteurella sp. Fish Shellfish Immunol. 2019, 95, 650-658. [CrossRef] [PubMed]

23. Vasquez, I.; Cao, T.; Chakraborty, S.; Gnanagobal, H.; O’Brien, N.; Monk, J.; Boyce, D.; Westcott, J.D.; Santander, J. Comparative Genomics Analysis of Vibrio anguillarum Isolated from Lumpfish (Cyclopterus lumpus) in Newfoundland Reveal Novel Chromosomal Organizations. Microorganisms 2020, 8, 1666. [CrossRef] [PubMed]

24. Erkinharju, T.; Dalmo, R.A.; Hansen, M.; Seternes, T. Cleaner fish in aquaculture: Review on diseases and vaccination. Rev. Aquac. 2021, 13, 189-237. [CrossRef] 
25. Frans, I.; Michiels, C.W.; Bossier, P.; Willems, K.A.; Lievens, B.; Rediers, H. Vibrio anguillarum as a fish pathogen: Virulence factors, diagnosis and prevention. J. Fish Dis. 2011, 34, 643-661. [CrossRef]

26. Holm, K.O.; Nilsson, K.; Hjerde, E.; Willassen, N.P.; Milton, D.L. Complete genome sequence of Vibrio anguillarum strain NB10, a virulent isolate from the Gulf of Bothnia. Stand. Genomic Sci. 2015, 10, 60. Available online: https://www.ncbi.nlm.nih.gov/ pubmed/26380645 (accessed on 15 June 2021). [CrossRef]

27. Mikkelsen, H.; Lund, V.; Larsen, R.; Seppola, M. Vibriosis vaccines based on various sero-subgroups of Vibrio anguillarum O2 induce specific protection in Atlantic cod (Gadus morhua L.) juveniles. Fish Shellfish Immunol. 2011, 30, 330-339. [CrossRef]

28. Chakraborty, S.; Cao, T.; Hossain, A.; Gnanagobal, H.; Vasquez, I.; Boyce, D.; Santander, J. Vibrogen-2 vaccine trial in lumpfish (Cyclopterus lumpus) against Vibrio anguillarum. J. Fish Dis. 2019, 42, 1057-1064. [CrossRef]

29. Dadar, M.; Chakraborty, S.; Dhama, K.; Prasad, M.; Khandia, R.; Hassan, S.; Munjal, A.; Tiwari, R.; Karthik, K.; Kumar, D.; et al. Advances in designing and developing vaccines, drugs and therapeutic Aapproaches to counter human papilloma virus. Front. Immunol. 2018, 9, 2478. [CrossRef]

30. Plant, K.P.; Lapatra, S.E. Advances in fish vaccine delivery. Dev. Comp. Immunol. 2011, 35, 1256-1262. [CrossRef] [PubMed]

31. Mutoloki, S.; Munangandu, H.M.; Evensen, O. Oral Vaccination of fish-antigen preparations, uptake, and immune induction. Front. Immunol. 2015, 6, 519. [CrossRef]

32. Campbell, R.; Adams, A.; Tatner, M.F.; Chair, M.; Sorgeloos, P. Uptake of Vibrio anguillarum vaccine by artemia salina as a potential oral delivery system to fish fry. Fish Shellfish Immunol. 1993, 3, 451-459. [CrossRef]

33. Lin, C.C.; Lin, J.H.Y.; Chen, M.S.; Yang, H.L. An oral nervous necrosis virus vaccine that induces protective immunity in larvae of grouper (Epinephelus coioides). Aquaculture 2007, 268, 265-273. [CrossRef]

34. Chen, Y.M.; Shih, C.H.; Liu, H.C.; Wu, C.L.; Lin, C.C.; Wang, H.C.; Chen, T.Y.; Yang, H.L.; Lin, J.H.Y. An oral nervous necrosis virus vaccine using Vibrio anguillarum as an expression host provides early protection. Aquaculture 2011, 321, 26-33. [CrossRef]

35. Sambrook, J.; Russell, W. Molecular Cloning; A Laboratory Manual, 3rd ed.; Cold Spring Harbor Press: New York, NY, USA, 2001.

36. Leboffe, M.J.; Pierce, B.E. Microbiology: Laboratory Theory \& Application; Morton Publishing: Englewood, CO, USA, 2019.

37. Eslamloo, K.; Kumar, S.; Caballero-Solares, A.; Gnanagobal, H.; Santander, J.; Rise, M.L. Profiling the transcriptome response of Atlantic salmon head kidney to formalin-killed Renibacterium salmoninarum. Fish Shellfish Immunol. 2020, 98, 937-949. [CrossRef] [PubMed]

38. Santander, J.; Golden, G.; Wanda, S.Y.; Curtiss, R., 3rd. Fur-regulated iron uptake system of Edwardsiella ictaluri and its influence on pathogenesis and immunogenicity in the catfish host. Infect. Immun. 2012, 80, 2689-2703. [CrossRef] [PubMed]

39. Vasquez, I.; Cao, T.; Hossain, A.; Valderrama, K.; Gnanagobal, H.; Dang, M.; Leeuwis, R.H.J.; Ness, M.; Campbell, B.; Gendron, R.; et al. Aeromonas salmonicida infection kinetics and protective immune response to vaccination in sablefish (Anoplopoma fimbria). Fish Shellfish Immunol. 2020, 104, 557-566. [CrossRef] [PubMed]

40. Valderrama, K.; Soto-Davila, M.; Segovia, C.; Vasquez, I.; Dang, M.; Santander, J. Aeromonas salmonicida infects Atlantic salmon (Salmo salar) erythrocytes. J. Fish Dis. 2019, 42, 1601-1608. [CrossRef] [PubMed]

41. Wessman, P.; Hakansson, S.; Leifer, K.; Rubino, S. Formulations for freeze-drying of bacteria and their influence on cell survival. J. Vis. Exp. 2013. [CrossRef]

42. Fissell, W.H.; Manley, S.; Dubnisheva, A.; Glass, J.; Magistrelli, J.E.A.N.; Fleischman, A.J.; Zydney, A.L.; Roy, S. Ficoll is not a rigid sphere. Am. J. Physiol. Renal Physiol. 2007, 293, F1209-F1213. [CrossRef] [PubMed]

43. Inman, J.K. Thymus-independent antigens: The preparation of covalent, hapten-ficoll conjugates. J. Immunol. 1975, 114 Pt 1 , 704-709.

44. Amlot, P.L.; Hayes, A.E.; Gray, D.; Gordon-Smith, E.C.; Humphrey, J.H. Human immune responses in vivo to protein (KLH) and polysaccharide (DNP-Ficoll) neoantigens: Normal subjects compared with bone marrow transplant patients on cyclosporine. Clin. Exp. Immunol. 1986, 64, 125-135.

45. Anderson, D.P.; Merchant, B.; Dixon, O.W.; Schott, C.F.; Lizzio, E.F. Flush exposure and injection immunization of rainbow trout to selected DNP conjugates. Dev. Comp. Immunol. 1983, 7, 261-268. [CrossRef]

46. Milley, B.; Kiwan, R.; Ott, G.S.; Calacsan, C.; Kachura, M.; Campbell, J.D.; Kanzler, H.; Coffman, R.L. Optimization, Production, and Characterization of a CpG-Oligonucleotide-Ficoll Conjugate Nanoparticle Adjuvant for Enhanced Immunogenicity of Anthrax Protective Antigen. Bioconjug. Chem. 2016, 27, 1293-1304. [CrossRef]

47. Amend, D.F. Potency Testing of Fish Vaccines. Fish Biologics: Serodiagnostics and Vaccines. 1981, Volume 49, pp. 447-454. Available online: https:/ / www.scirp.org/(S(vtj3fa45qm1ean45vvffcz55))/ reference/ReferencesPapers.aspx?ReferenceID=1919 013 (accessed on 15 June 2021).

48. Pfaffl, M.W. A new mathematical model for relative quantification in real-time RT-PCR. Nucleic Acids Res. 2001, 29, e45. [CrossRef]

49. Vandesompele, J.; De Preter, K.; Pattyn, F.; Poppe, B.; Van Roy, N.; De Paepe, A.; Speleman, F. Accurate normalization of real-time quantitative RT-PCR data by geometric averaging of multiple internal control genes. Genome Biol. 2002, 3, RESEARCH0034. [CrossRef] [PubMed]

50. Livak, K.J.; Schmittgen, T.D. Analysis of relative gene expression data using real-time quantitative PCR and the 2(Delta Delta C(T)) Method. Methods 2001, 25, 402-408. [CrossRef] [PubMed]

51. Soto-Davila, M.; Hossain, A.; Chakraborty, S.; Rise, M.L.; Santander, J. Aeromonas salmonicida subsp. salmonicida early infection and immune response of Atlantic cod (Gadus morhua L.) primary macrophages. Front. Immunol. 2019, 10, 1237. [CrossRef] [PubMed] 
52. Villumsen, K.R.; Neumann, L.; Ohtani, M.; Strom, H.K.; Raida, M.K. Oral and anal vaccination confers full protection against enteric redmouth disease (ERM) in rainbow trout. PLoS ONE 2014, 9, e93845. [CrossRef] [PubMed]

53. Lin, J.H.; Yu, C.C.; Lin, C.C.; Yang, H.L. An oral delivery system for recombinant subunit vaccine to fish. Dev. Biol 2005, 121, 175-180.

54. Min, W.; Lillehoj, H.S.; Burnside, J.; Weining, K.C.; Staeheli, P.; Zhu, J.J. Adjuvant effects of IL-1beta, IL-2, IL-8, IL-15, IFN-alpha, IFN-gamma TGF-beta4 and lymphotactin on DNA vaccination against Eimeria acervulina. Vaccine 2001, 20, 267-274. [CrossRef]

55. Xu, C.; Guo, T.C.; Mutoloki, S.; Haugland, O.; Evensen, O. Gene expression studies of host response to Salmonid alphavirus subtype 3 experimental infections in Atlantic salmon. Vet. Res. 2012, 43, 78. [CrossRef]

56. Kumari, J.; Bogwald, J.; Dalmo, R.A. Vaccination of Atlantic salmon, Salmo salar L.; with Aeromonas salmonicida and infectious pancreatic necrosis virus (IPNV) showed a mixed Th1/Th2/Treg response. J. Fish Dis. 2013, 36, 881-886. [CrossRef]

57. Ohtani, M.; Hikima, J.; Kondo, H.; Hirono, I.; Jung, T.S.; Aoki, T. Evolutional conservation of molecular structure and antiviral function of a viral RNA receptor, LGP2, in Japanese flounder, Paralichthys olivaceus. J. Immunol. 2010, 185, 7507-7517. [CrossRef]

58. Chang, M.; Collet, B.; Nie, P.; Lester, K.; Campbell, S.; Secombes, C.J.; Zou, J. Expression and functional characterization of the RIG-I-like receptors MDA5 and LGP2 in Rainbow trout (Oncorhynchus mykiss). J. Virol. 2011, 85, 8403-8412. [CrossRef] [PubMed]

59. van der Veen, A.G.; Maillard, P.V.; Schmidt, J.M.; Lee, S.A.; Deddouche-Grass, S.; Borg, A.; Kjaer, S.; Snijders, A.P.; Reis e Sousa, C. The RIG-I-like receptor LGP2 inhibits Dicer-dependent processing of long double-stranded RNA and blocks RNA interference in mammalian cells. EMBO J. 2018, 37. [CrossRef]

60. Zhang, Q.M.; Zhao, X.; Li, Z.; Wu, M.; Gui, J.F.; Zhang, Y.B. Alternative splicing transcripts of Zebrafish LGP2 Ggene Ddifferentially contribute to IFN antiviral response. J. Immunol. 2018, 200, 688-703. [CrossRef]

61. Arancibia, S.A.; Beltran, C.J.; Aguirre, I.M.; Silva, P.; Peralta, A.L.; Malinarich, F.; Hermoso, M.A. Toll-like receptors are key participants in innate immune responses. Biol. Res. 2007, 40, 97-112. [CrossRef]

62. Jayaramu, P.K.; Tripathi, G.; Pavan Kumar, A.; Keezhedath, J.; Pathan, M.K.; Kurcheti, P.P. Studies on expression pattern of toll-like receptor 5 (TLR5) in Edwardsiella tarda infected Pangasianodon hypophthalmus. Fish Shellfish Immunol. 2017, 63, 68-73. [CrossRef]

63. Ji, J.; Rao, Y.; Wan, Q.; Liao, Z.; Su, J. Teleost-Specific TLR19 localizes to endosome, recognizes dsRNA, recruits TRIF, triggers both IFN and NF-kappaB pathways, and protects cells from grass carp reovirus infection. J. Immunol. 2018, 200, 573-585. [CrossRef]

64. Barton, G.M.; Medzhitov, R. Control of adaptive immune responses by Toll-like receptors. Curr. Opin. Immunol. 2002, 14, 380-383. [CrossRef]

65. Eggestol, H.O.; Lunde, H.S.; Ronneseth, A.; Fredman, D.; Petersen, K.; Mishra, C.K.; Furmanek, T.; Colquhoun, D.J.; Wergeland H.I.; Haugland, G.T. Transcriptome-wide mapping of signaling pathways and early immune responses in lumpfish leukocytes upon in vitro bacterial exposure. Sci. Rep. 2018, 8, 5261. [CrossRef] [PubMed]

66. Upadhyay, G. Emerging role of lymphocyte Aantigen-6 family of genes in cancer and immune cells. Front. Immunol. 2019, 10, 819. [CrossRef]

67. MacNeil, I.; Kennedy, J.; Godfrey, D.I.; Jenkins, N.A.; Masciantonio, M.; Mineo, C.; Gilbert, D.J.; Copeland, N.G.; Boyd, R.L.; Zlotnik, A. Isolation of a cDNA encoding thymic shared antigen-1. A new member of the Ly6 family with a possible role in T cell development. J. Immunol. 1993, 151, 6913-6923. [PubMed]

68. Mallya, M.; Campbell, R.D.; Aguado, B. Characterization of the five novel Ly- 6 superfamily members encoded in the MHC, and detection of cells expressing their potential ligands. Protein Sci. 2006, 15, 2244-2256. [CrossRef] [PubMed]

69. Loughner, C.L.; Bruford, E.A.; McAndrews, M.S.; Delp, E.E.; Swamynathan, S.; Swamynathan, S.K. Organization, evolution and functions of the human and mouse Ly6/uPAR family genes. Hum. Genom. 2016, 10, 10. [CrossRef] [PubMed]

70. Danilova, N.; Bussmann, J.; Jekosch, K.; Steiner, L.A. The immunoglobulin heavy-chain locus in zebrafish: Identification and expression of a previously unknown isotype, immunoglobulin Z. Nat. Immunol. 2005, 6, 295-302. [CrossRef] [PubMed]

71. Savan, R.; Aman, A.; Sato, K.; Yamaguchi, R.; Sakai, M. Discovery of a new class of immunoglobulin heavy chain from fugu. Eur. J. Immunol. 2005, 35, 3320-3331. [CrossRef]

72. Yasuike, M.; de Boer, J.; von Schalburg, K.R.; Cooper, G.A.; McKinnel, L.; Messmer, A.; So, S.; Davidson, W.S.; Koop, B.F. Evolution of duplicated IgH loci in Atlantic salmon, Salmo salar. BMC Genom. 2010, 11, 486. [CrossRef]

73. Schroeder, H.W.; Cavacini, L., Jr. Structure and function of immunoglobulins. J. Allergy Clin. Immunol. 2010, 125 (Suppl. 2), S41-S52. [CrossRef]

74. Bromley, S.K.; Mempel, T.R.; Luster, A.D. Orchestrating the orchestrators: Chemokines in control of T cell traffic. Nat. Immunol. 2008, 9, 970-980. [CrossRef]

75. Yan, Y.; Chen, R.; Wang, X.; Hu, K.; Huang, L.; Lu, M.; Hu, Q. CCL19 and CCR7 expression, signaling pathways, and adjuvant functions in viral Iinfection and prevention. Front. Cell Dev. Biol. 2019, 7, 212. [CrossRef]

76. Liu, F.; Wang, T.; Hu, Y.; Tian, G.; Secombes, C.J.; Wang, T. Expansion of fish CCL20_like chemokines by genome and local gene duplication: Characterisation and expression analysis of 10 CCL20_like chemokines in rainbow trout (Oncorhynchus mykiss). Dev. Comp. Immunol. 2020, 103, 103502. [CrossRef]

77. Buonocore, F.; Randelli, E.; Bird, S.; Secombes, C.J.; Costantini, S.; Facchiano, A.; Mazzini, M.; Scapigliati, G. The CD8alpha from sea bass (Dicentrarchus labrax L.): Cloning, expression and 3D modelling. Fish Shellfish Immunol. 2006, 20, 637-646. [CrossRef]

78. Moldenhauer, G.; Henne, C.; Karhausen, J.; Moller, P. Surface-expressed invariant chain (CD74) is required for internalization of human leucocyte antigen-DR molecules to early endosomal compartments. Immunology 1999, 96, 473-484. [CrossRef] 
79. Beswick, E.J.; Reyes, V.E. CD74 in antigen presentation, inflammation, and cancers of the gastrointestinal tract. World, J. Gastroenterol. 2009, 15, 2855-2861. [CrossRef]

80. Star, B.; Nederbragt, A.J.; Jentoft, S.; Grimholt, U.; Malmstrom, M.; Gregers, T.F.; Rounge, T.B.; Paulsen, J.; Solbakken, M.H.; Sharma, A.; et al. The genome sequence of Atlantic cod reveals a unique immune system. Nature 2011, 477, 207-210. [CrossRef]

81. Trowsdale, J.; Knight, J.C. Major histocompatibility complex genomics and human disease. Annu. Rev. Genom. Hum. Genet. 2013, 14, 301-323. [CrossRef]

82. Dijkstra, J.M.; Grimholt, U. Major histocompatibility complex (MHC) fragment numbers alone-in Atlantic cod and in general-do not represent functional variability. F1000Research 2018, 7, 963. [CrossRef] [PubMed]

83. Dubin, A.; Jorgensen, T.E.; Moum, T.; Johansen, S.D.; Jakt, L.M. Complete loss of the MHC II pathway in an anglerfish, Lophius piscatorius. Biol. Lett. 2019, 15, 20190594. [CrossRef]

84. Brown, J.A. The development of feeding behaviour in the lumpfish, Cyclopterus lumpus. J. Fish Biol. 1986, 29, 171-178. [CrossRef]

85. Imsland, A.K.D.; Danielsen, M.; Jonassend, T.M.; Hangstadd, T.A.; Falk-Petersenc, I.B. Effect of incubation temperature on eggs and larvae of lumpfish (Cyclopterus lumpus). Aquaculture 2019, 498, 217-222. [CrossRef]

86. Galeotti, M.; Romano, N.; Volpatti, D.; Bulfon, C.; Brunetti, A.; Tiscar, P.G.; Mosca, F.; Bertoni, F.; Marchetti, M.G.; Abelli, L. Innovative vaccination protocol against vibriosis in Dicentrarchus labrax (L.) juveniles: Improvement of immune parameters and protection to challenge. Vaccine 2013, 31, 1224-1230. [CrossRef] [PubMed]

87. Johnson, K.A.; Flynn, J.K.; Amend, D.F. Duration of immunity in salmonids vaccinated by direct immersion with Yersinia ruckeri and Vibrio anguillarum bacterins. J. Fish Dis. 1983, 5, 207-213. [CrossRef]

88. Johnson, K.A.; Amend, D.F. Comparison of efficacy of several delivery methods using Yersinia ruckeri bacterin on rainbow trout, Salmo gairdneri Richardson. J. Fish Dis. 1983, 6, 331-336. [CrossRef]

89. Chettri, J.K.; Jaafar, R.M.; Skov, J.; Kania, P.W.; Dalsgaard, I.; Buchmann, K. Booster immersion vaccination using diluted Yersinia ruckeri bacterin confers protection against ERM in rainbow trout. Aquaculture 2015, 440, 1-5. [CrossRef]

90. Johnson, K.A.; Amend, D.F. Efficacy of Vibrio anguillarum and Yersinia ruckeri bacterins applied by oral and anal intubation of salmonids. J. Fish Dis. 1983, 6, 473-476. [CrossRef] 